\author{
آبشستخى موضعى در آرايش تك ستونى گروه پايههاى بِل \\ سيد سعيد اخروى و سعيد گوهرى

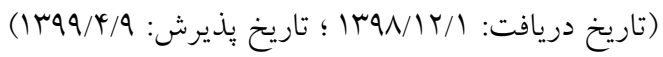

جكيده

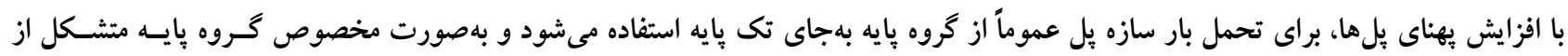

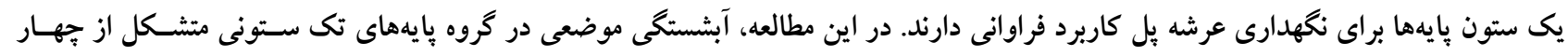

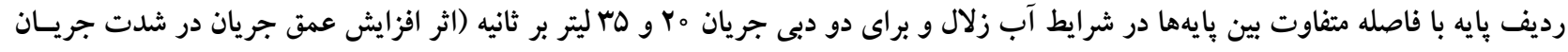

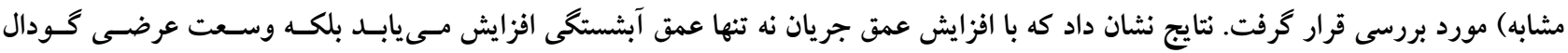

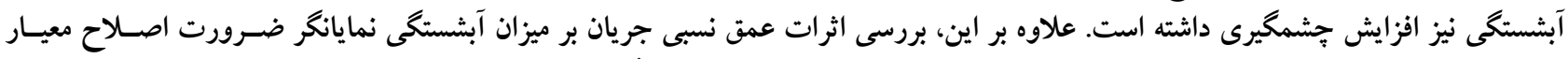

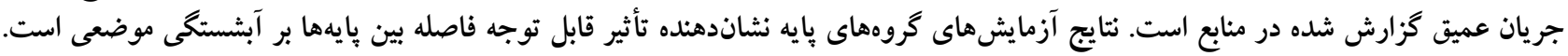

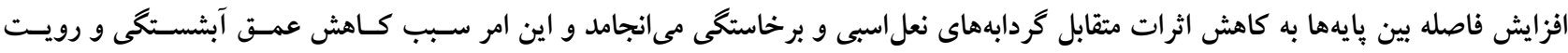

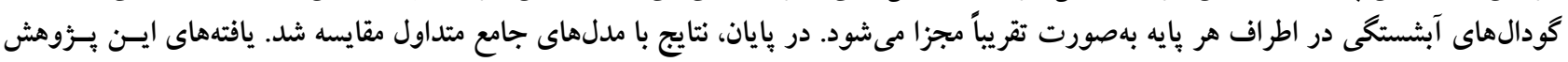

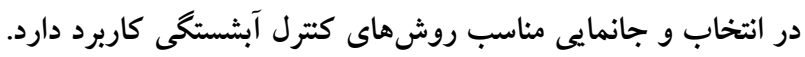

وازههاى كليدى: آبشستخى موضعى، گروه بايه، عمق آبشستخى، زمان، فاصله بين بايهها

\footnotetext{
ا. كروه مهندسى آب، دانشكده كشاورزى، دانشكاه بوعلى سينا، همدان، ايران

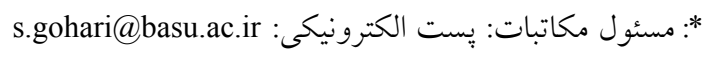


بر فرايندهاى آبشستــى در مجموعـه بِايـههـا مـرتبط دانسـت.

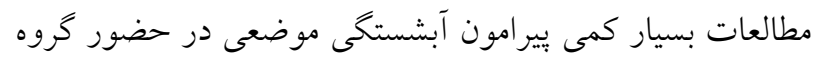

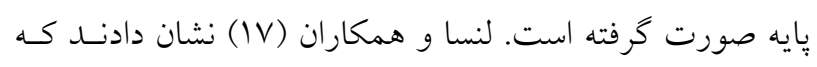

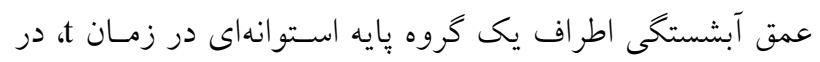

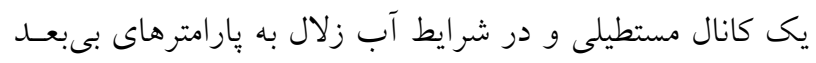

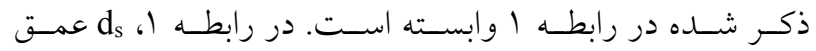

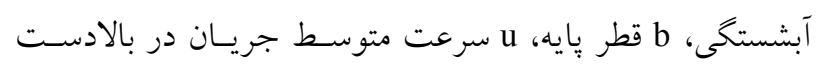

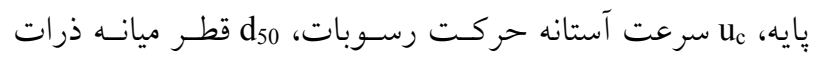

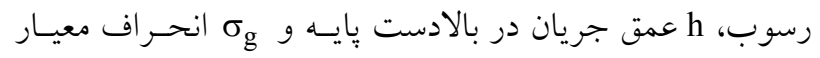

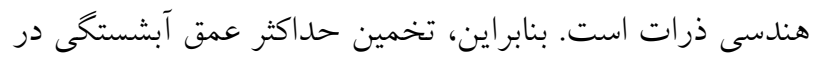

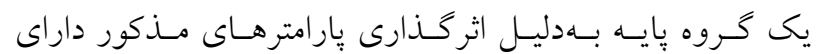

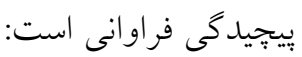
$\frac{\mathrm{d}_{\mathrm{s}}}{\mathrm{b}}=\varphi\left(\frac{\mathrm{h}}{\mathrm{b}} ; \frac{\mathrm{u}}{\mathrm{u}_{\mathrm{c}}} ; \frac{\mathrm{b}}{\mathrm{d}_{50}} ; \frac{\mathrm{ut}}{\mathrm{b}} ; \frac{\mathrm{s}}{\mathrm{b}} ; \sigma_{\mathrm{g}} ; \theta ; \mathrm{m} ; \mathrm{n}\right)$

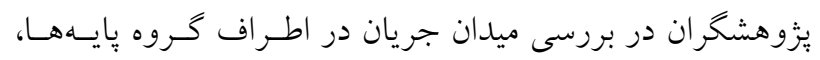

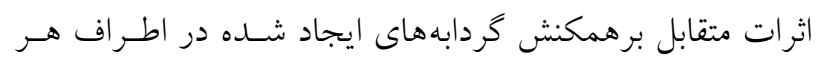

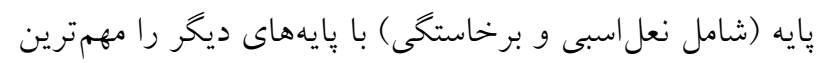

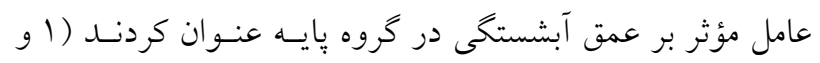

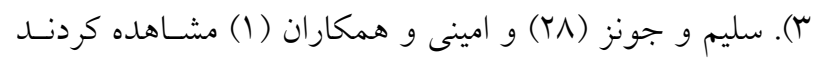

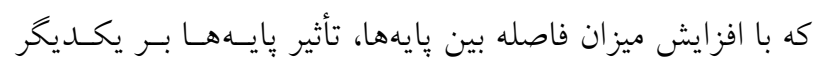

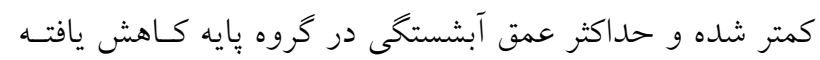

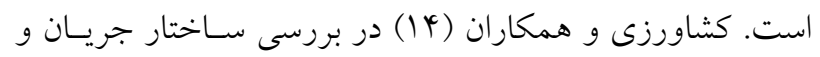

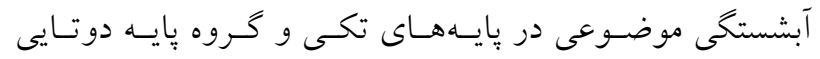

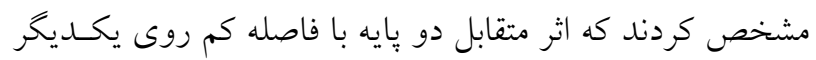

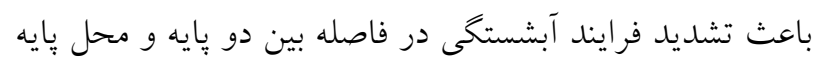

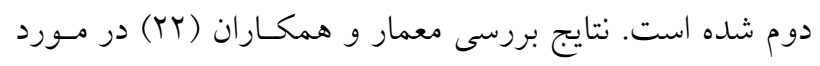

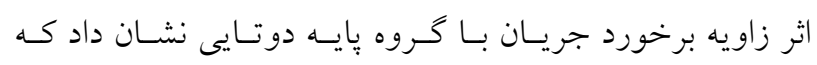

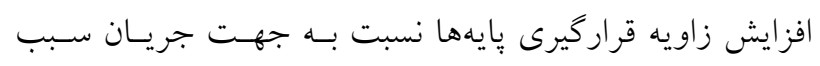

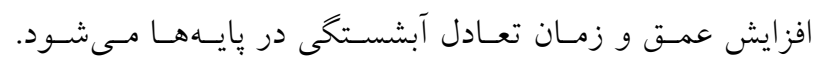

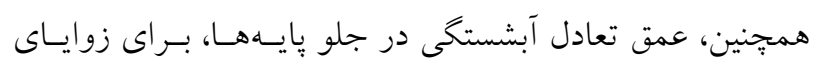

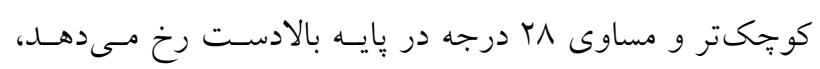

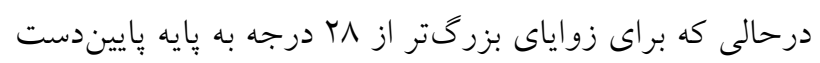

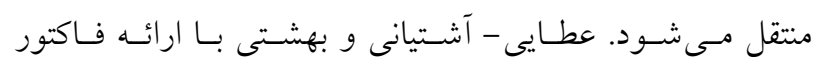

آبشستكى موضعى در اطراف سازه بِايه يل با تضـعيف هي يـل

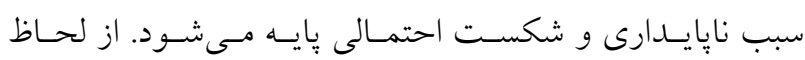

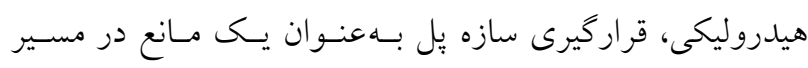

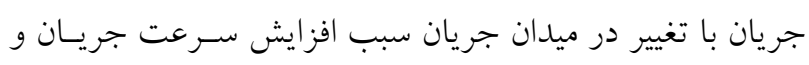
تنش برشى بستر شده كه به فرسايش رسـوبات در نـواحى بايـهـ

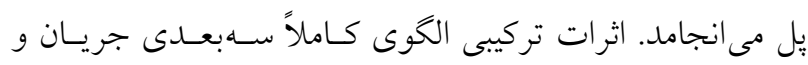

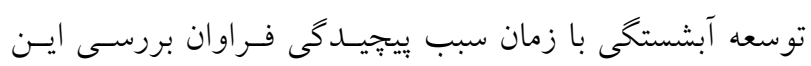

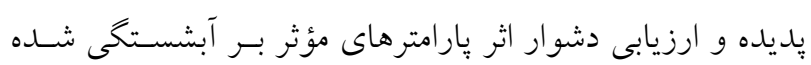

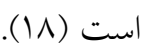

يززوهشخران متعددى به بررسى آبشستكى موضسعى بيرامـون

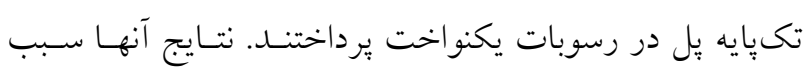

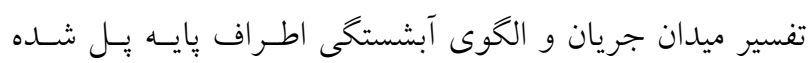

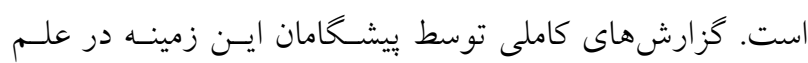

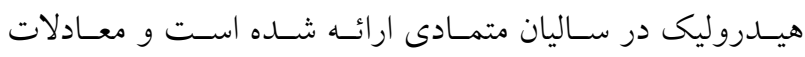

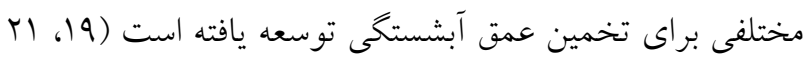

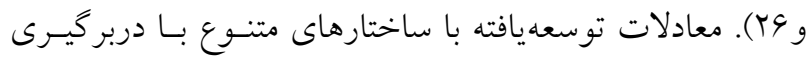

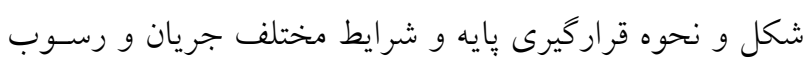

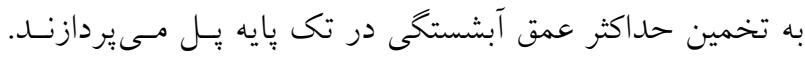

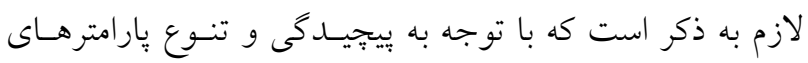

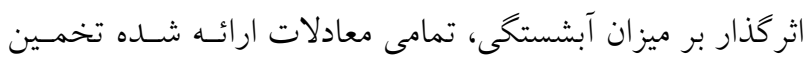

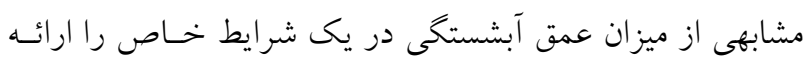

نمى كنند (11) (11)

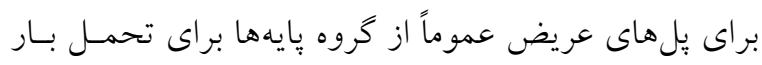

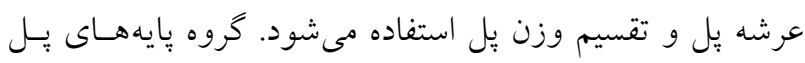

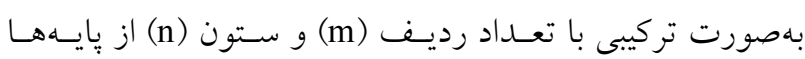

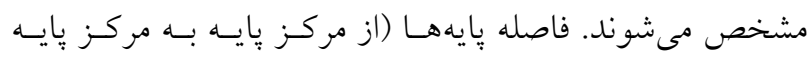

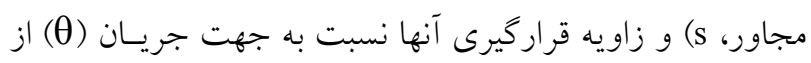

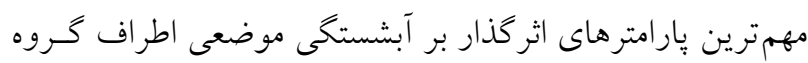

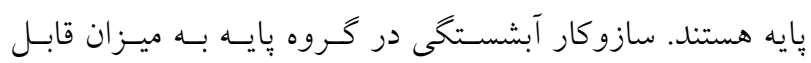

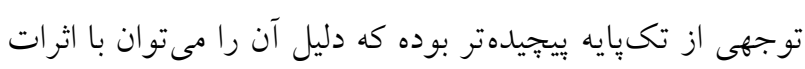

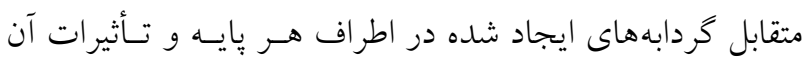


تكى بِايه و كَروههـاى بايسه و ه) مقايسـه نتسايج آزمـايشهـاى

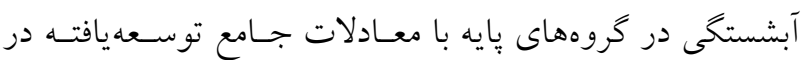

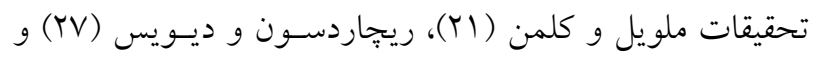
شبرد و رنا (Y9) صورت كرفته است.

\section{مشخصات آزمايشها}

يُزوهش حاضر در آزمايشكاه هيدروليك گروه مهندسى آب در دانشگاه بوعلى سينا همدان انجام گرفته است. فلوم آزمايشخاهى

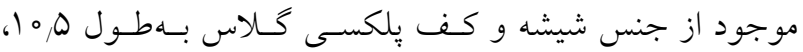

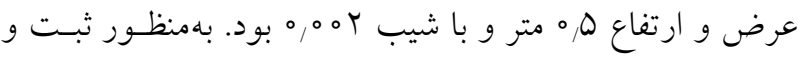

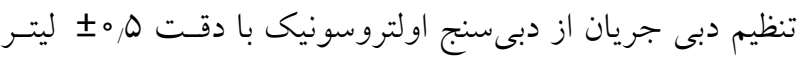

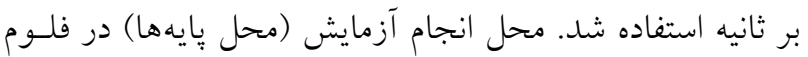

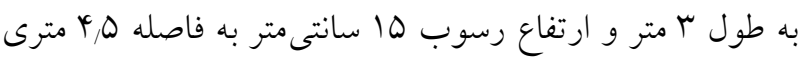

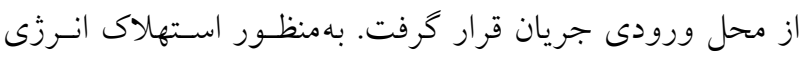
جريان در ورودى، كـاهش طـول منطقـه ورودى و ايجـاد لايسه مرزى توسعهيافته، محل ورودى به شبكه لانهزنبـورى و منطقسه ورديه

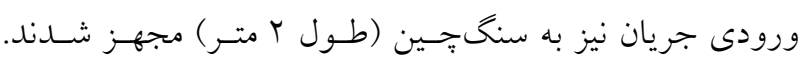

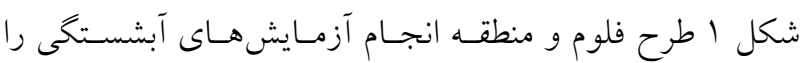
نشان مى دهد. در يزوهش حاضر، تمامى آزمايشهاى تكىيايه و گروه هِايسه با پايههاى استوانهاى به جنس تفلون با قطر با سـانتى متـر انجـام شد. دليل انتخاب ميزان قطر مـــكور، معيـار ملويـل و سـودرلند

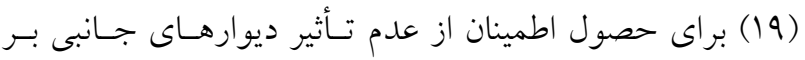

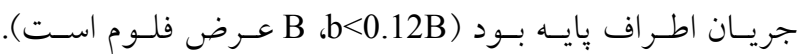

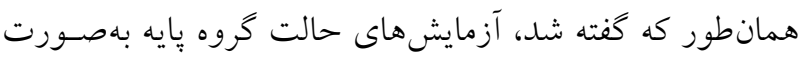
تكستونى همراه با جهار رديـف پِايـهـ بـوده و تفــاوت آنهـا در فاصله بايهها است. در تمامى آزمايشهاى صورت گرفته، بايهها

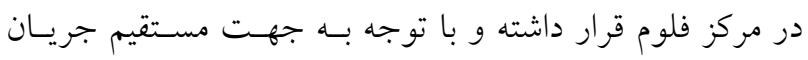
زاويه حمله جريان در اين حالت صفر است و اثر اين بارامتر در

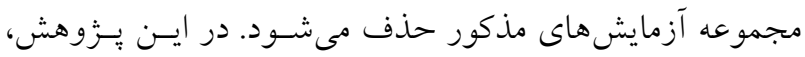
فاصله مركز تا مركز بايهها بهصورت دو، سه و جهار برابـر قطر

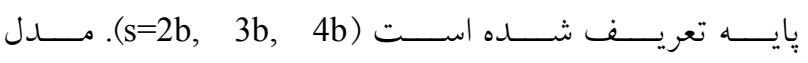

تصحيحى به هدف افزايش دقت تخمين حداكثر عمق آبشستخى

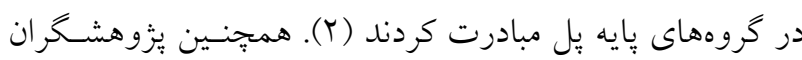

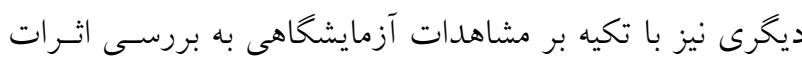

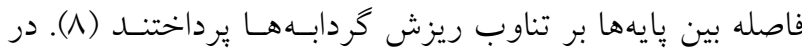

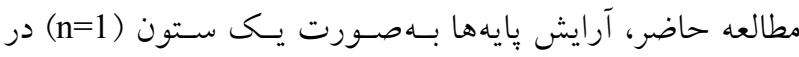

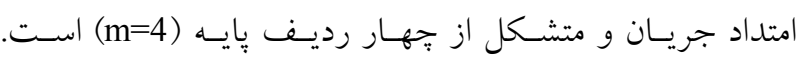
آرايشهاى تكستونى بلصورت وسيع براى يوشش عرشه يل ها

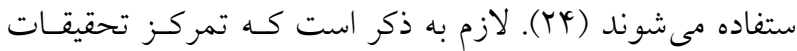

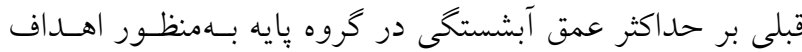

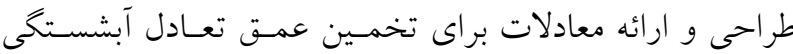

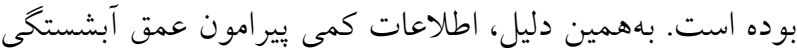

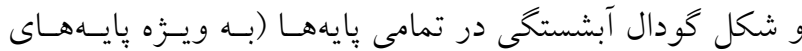
پاييندست) موجود است. كيخايى و همكاران (10)، حيدريور و همكاران (rا) و دياب و همكــاران (V) در تحقيقـاتى در مـورد هندسه كودال آبشستخى و روشهـاى كتــرل و كـاهش ميـزان

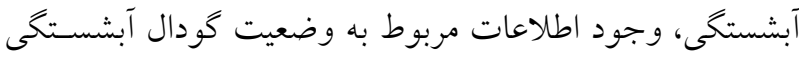
در طراحى بهينه بِايههاى بِل در رودخانه (بهويزّه كروه بِايههـاى

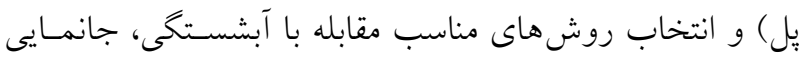

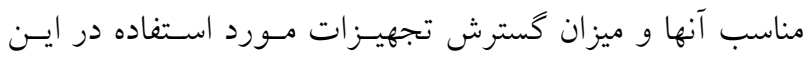
روشها راضرورى دانستند.

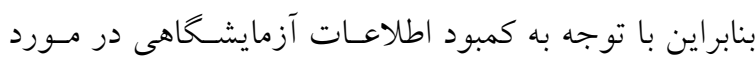

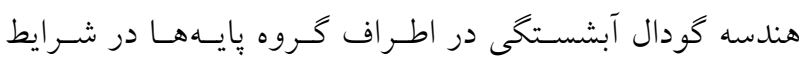

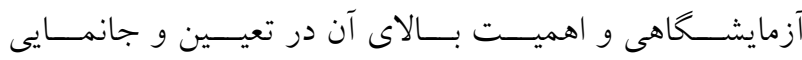

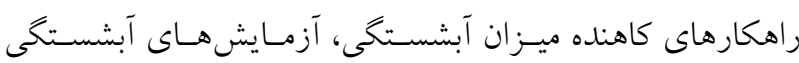

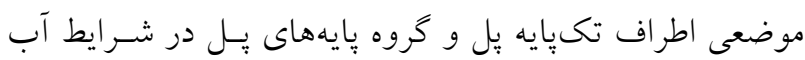

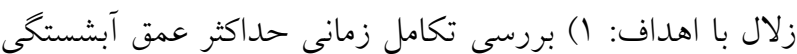

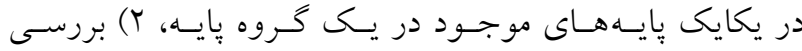

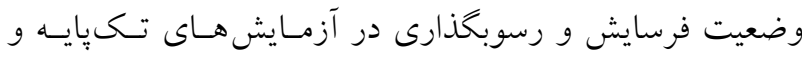

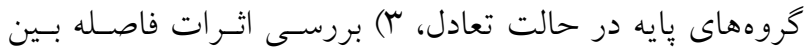

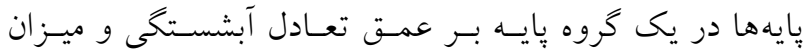

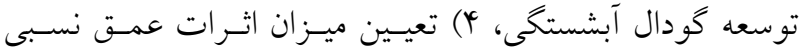

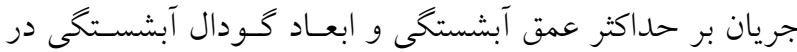



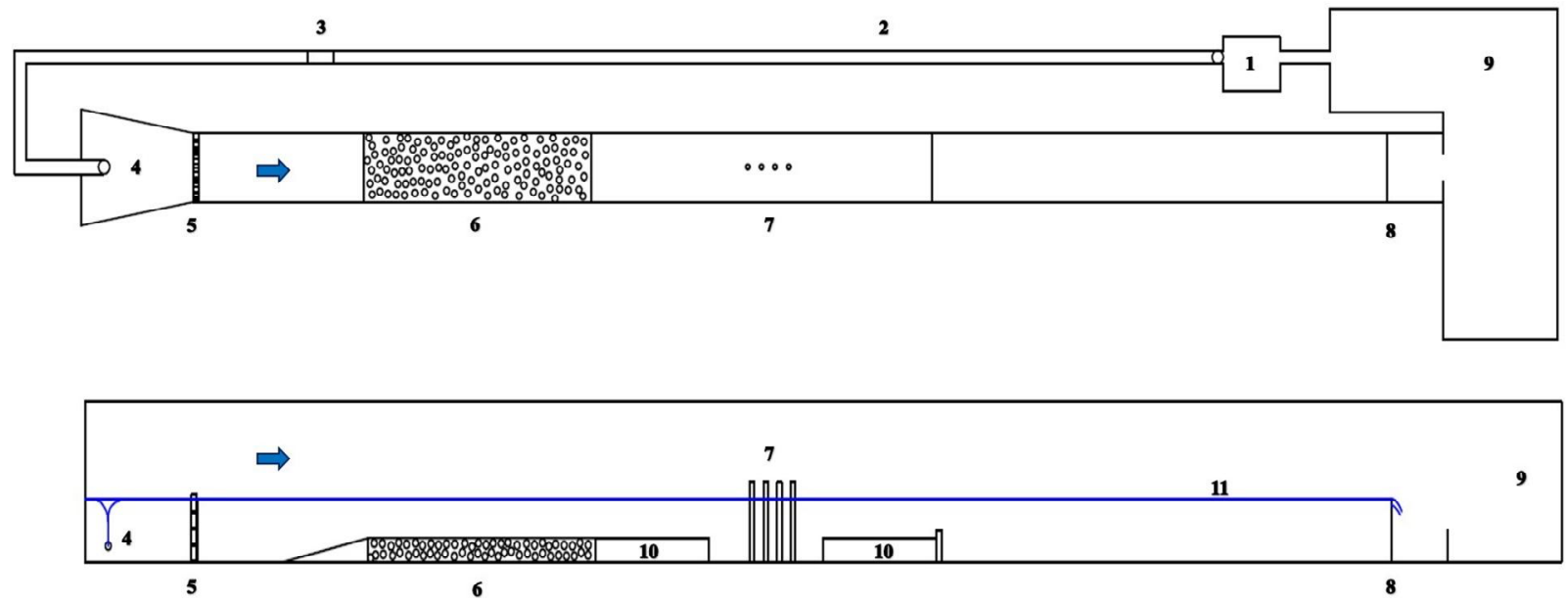

() بمب و اينورتور (Y) لوله انتقال آب r) دبى سنج اولتروسونيكى ع) مخزن ودودى جريان 0) شبكه آجرى در ودودى جريان 7) منطقه سنكجين (V) محل انجام آزمايش و قراركيرى بايهما () دريجه تنظيم سطح آب 9) مخزن انتهايى فلوم •) سكوماى اطراف منطقه آزمايش I(I) سطح جريان
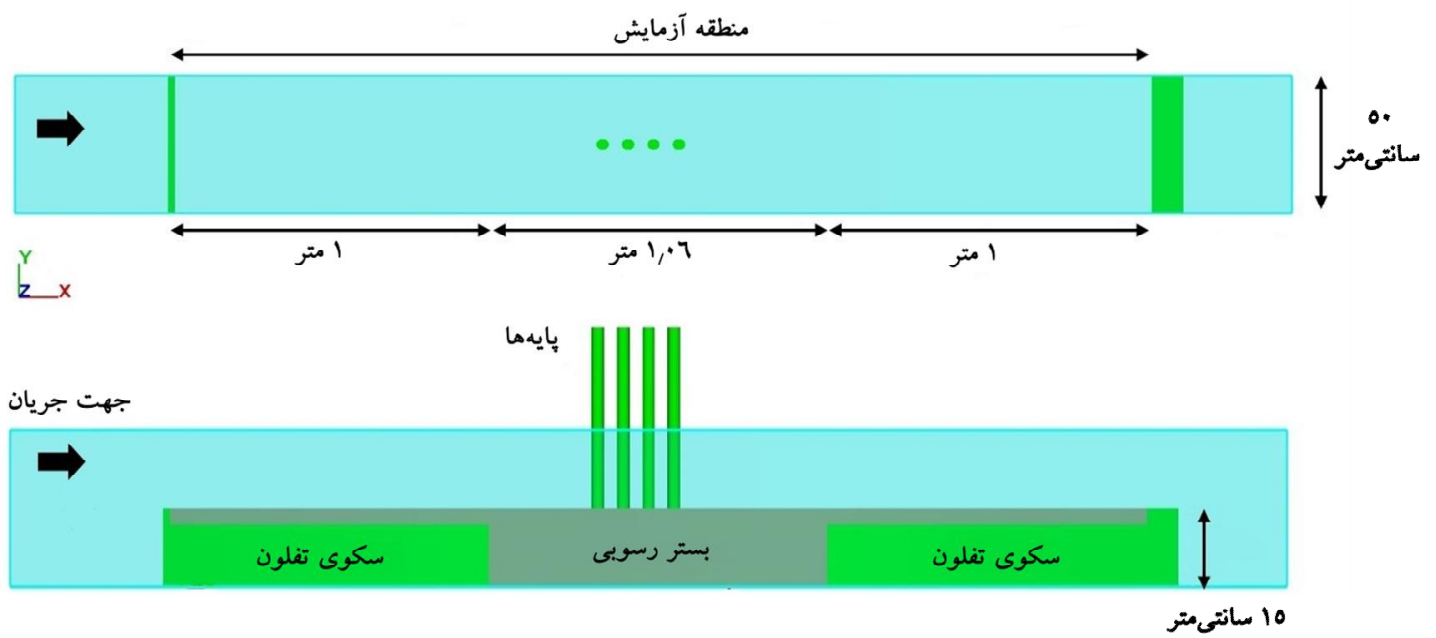

شكل 1. طرح مشخصات فلوم آزمايشحاهى و موقعيت محل انجام آزمايش

يكنواخت و در غير اينصورت غيريكنو اخت درنظر كرفتـه مسى شوند (9). علاوه بر اين، اخر ضريب يكنواختى ذرات (بـهويـزه

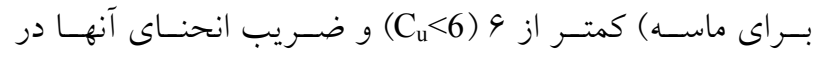

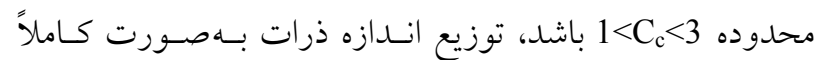
يكنواخت درنظر كرفته مىشود. از آنجايى كـه رسـوبات مـورد

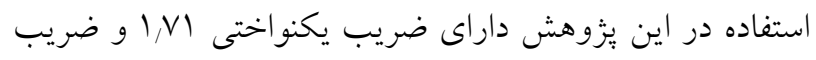

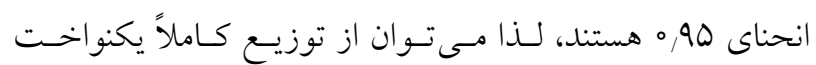
رسوبات اطمينان حاصل كرد (UD). نمودار توزيـع انـدازه ذرات رسوب در اين يزوهش در شكل ب نشان داده شده است.
كروه يايههاى مورد استفاده در اين يـزّوهش در شـكل r نشـان داده شده است

ذرات رسوبى مورد اسـتفاده در ايـن بـرّوهش داراى انـدازه متوسط r ميلى متر بوده (d50) و ميزان انحراف معيار هندسى آنها نيز معادل با 1, 1, است. معيار اصسلى غيريكنـو اختى رسـوبات بـا

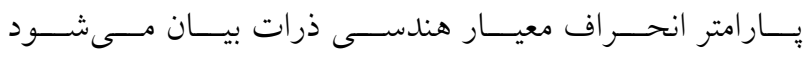

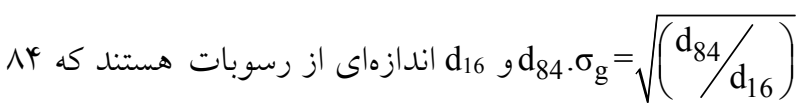
و 19 درصد ذرات در نمودار توزيع اندازه ذرات از آنها كوجى

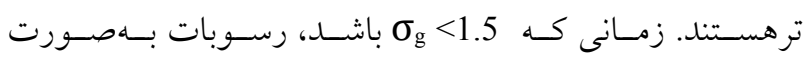




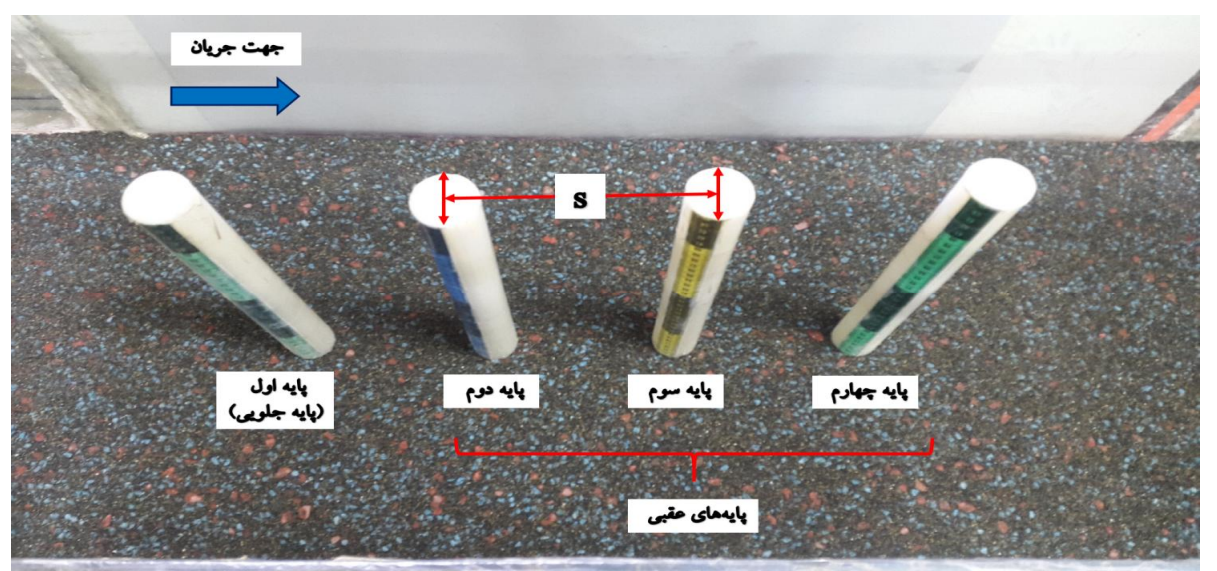

شكل r. مدل گروه بايه مورد استفاده (يك ستون (n) در امتداد جريان بههمراه جهار رديف بايه (m) عمود بر امتداد جريان)

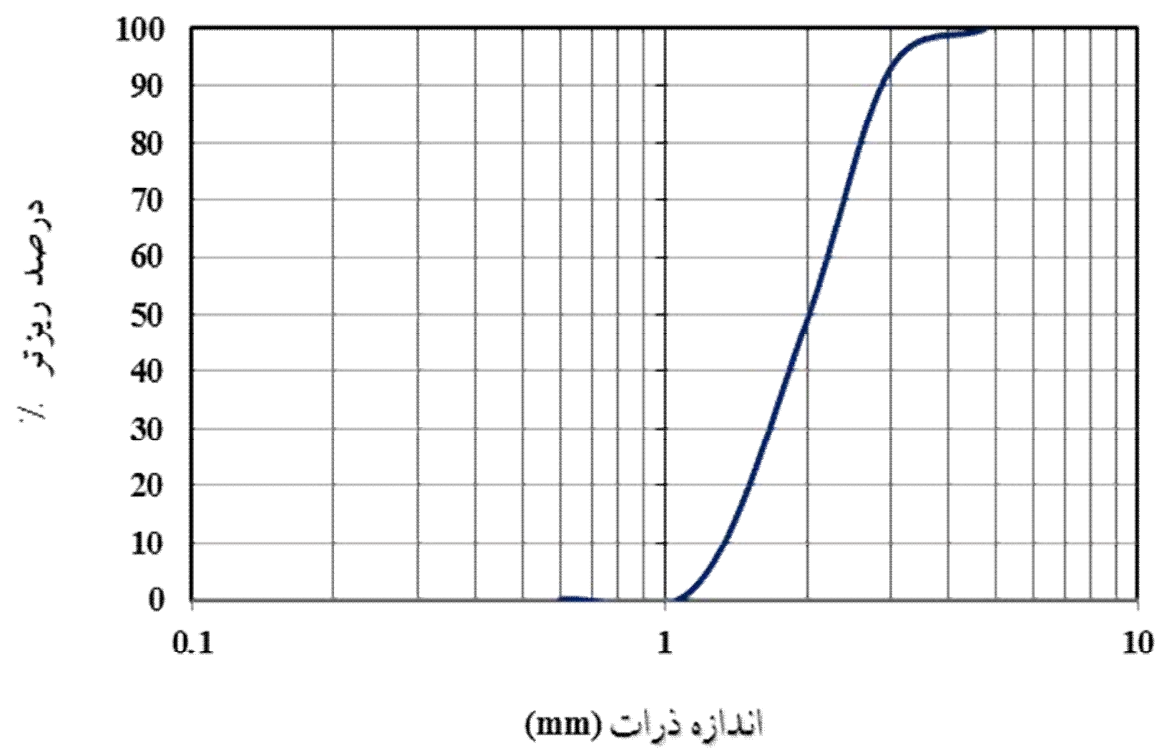

شكل r. نمودار توزيع اندازه ذرات رسوبات

مشخص شود. براساس فرايند سعى و خطا ميزان عمق جريـان

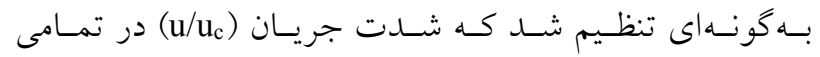

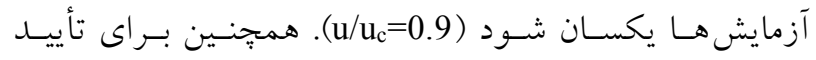

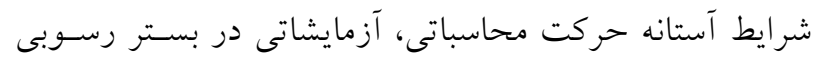
مورد نظر و بلدون حضور بايه صورت كرفت تا سرعت جريان

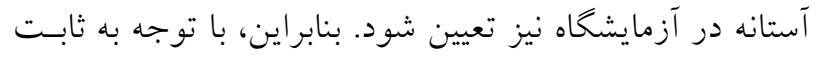

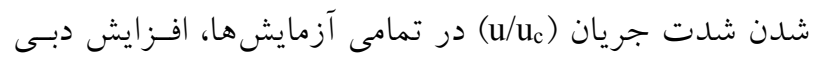

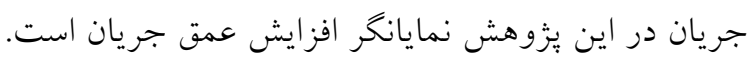
$\frac{\mathrm{u}_{\mathrm{c}}}{\mathrm{u}_{*_{\mathrm{c}}}}=5.75 \log \left(5.53 \frac{\mathrm{h}}{\mathrm{d}_{50}}\right)$
آزمايشهاى آبشستخى موضسعى در ايسن يــزوهش در دو دبسى

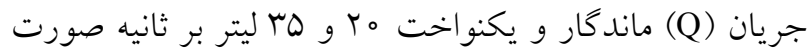

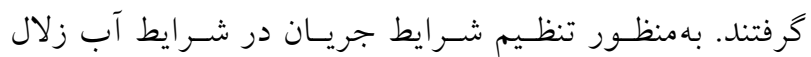

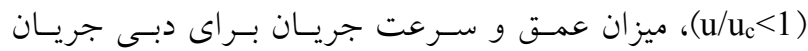

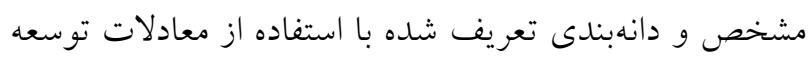

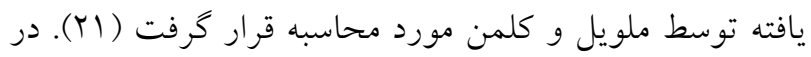

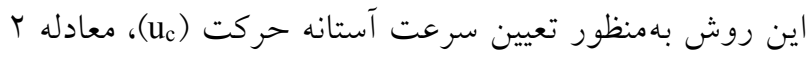

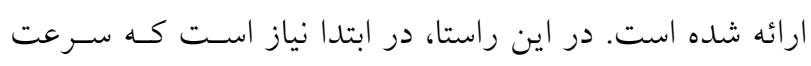

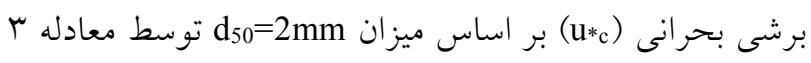


شكل †، شبكه نقاط مذكور بهمنظـور برداشـت پِّتى و بلنـدى

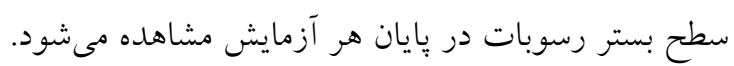

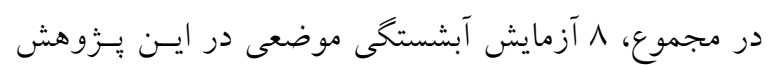

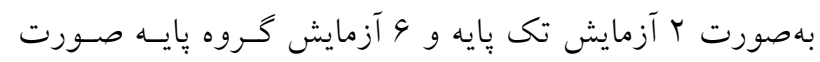

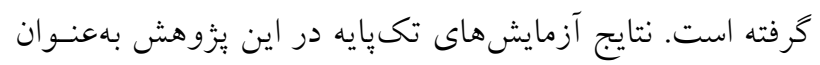

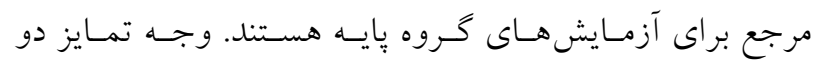

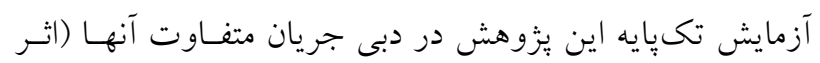

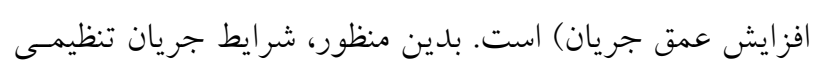

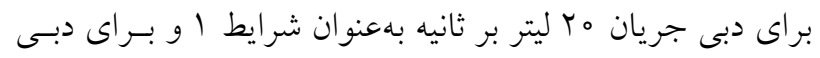

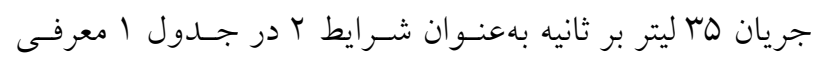

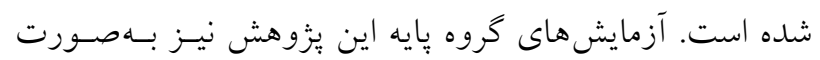

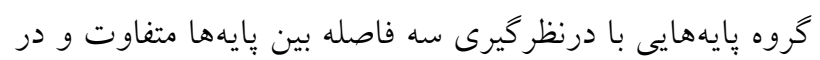

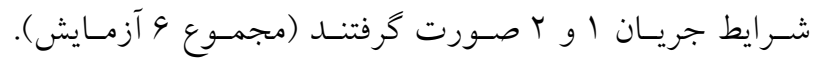

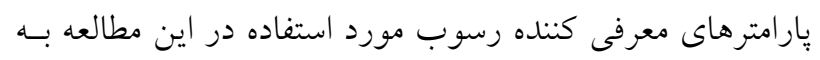

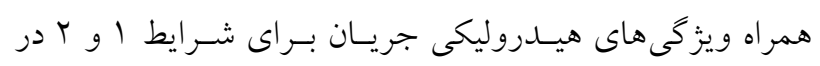
جدول ا خلاصه شده است.

\section{نتايج و بحث} آبشستخى در تكى ايايه

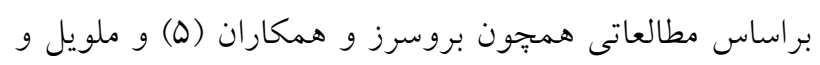

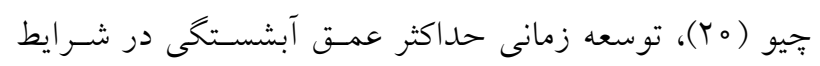

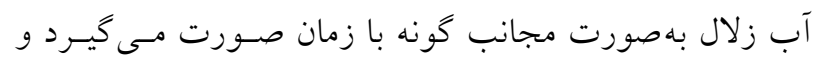

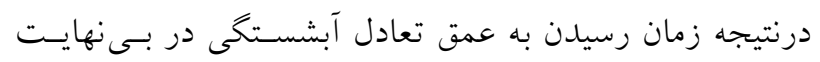

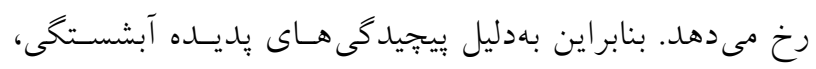

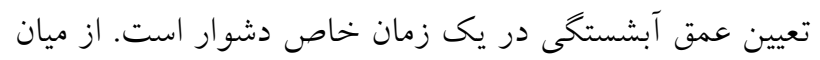

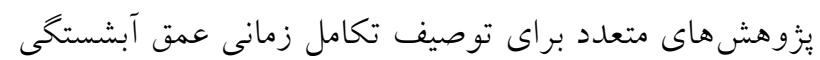

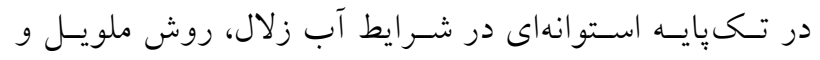

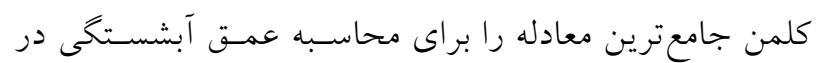

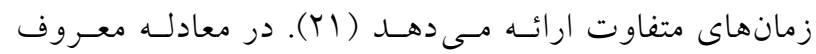

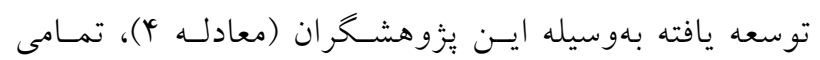

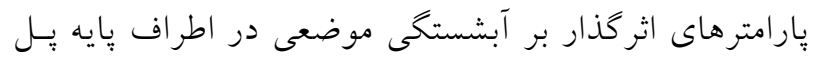

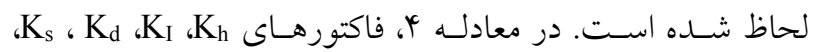

$\mathrm{u}_{*_{\mathrm{c}}}=0.0305 \mathrm{~d}_{50}^{0.5}-6.5 \times 10^{-3} \mathrm{~d}_{50}^{-1} \quad 1 \mathrm{~mm} \leq \mathrm{d}_{50}<100 \mathrm{~mm}$

بمنظور تنظيم مدت زمان انجام آزمايش هاى آبشستكى، از معيار

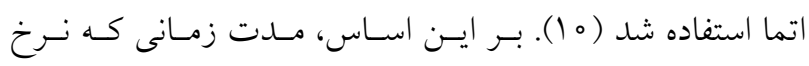
افزايشى عمق آبشستخى كمتر از يكى ميلىمتـر ( $)$ (

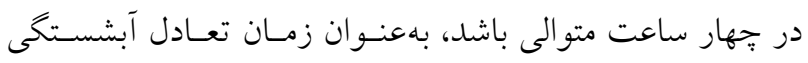

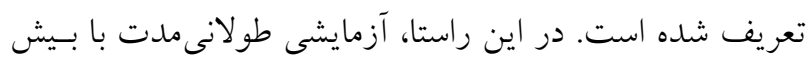

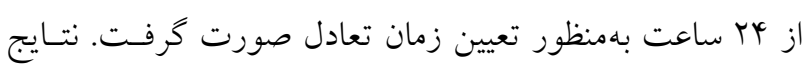

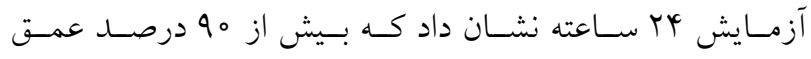

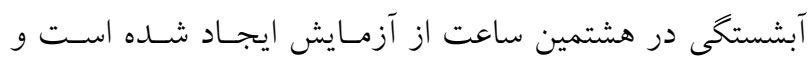

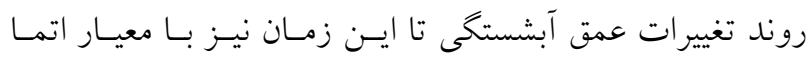

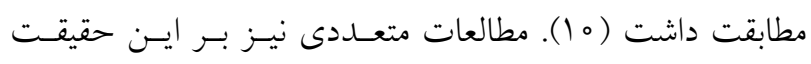

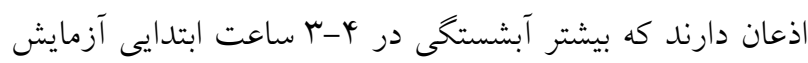

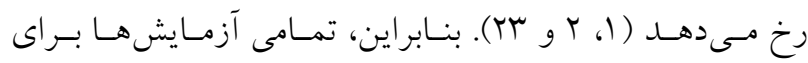

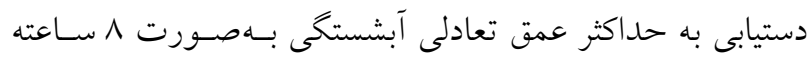

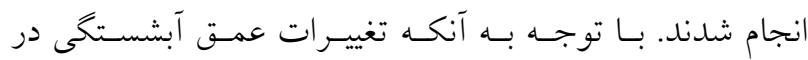

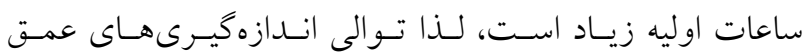
آبشستخى در ساعت اول بلهورت هر هـ دقيقه، ساعت دوم هـر

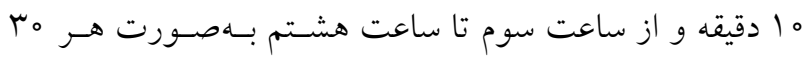

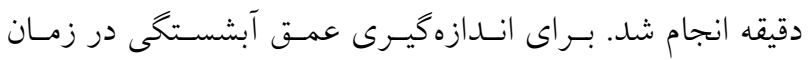
آزمايش از يك ليمنىمتر با دقت الميلىمتر استفاده شده است.

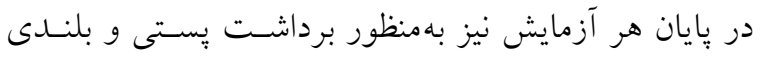

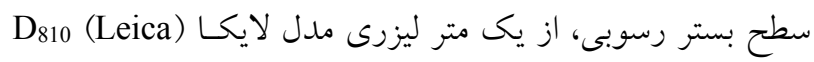

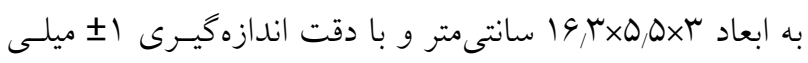

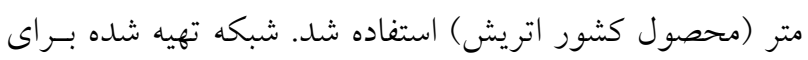

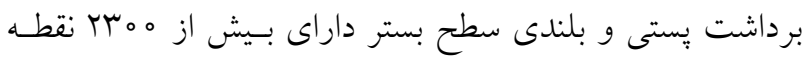

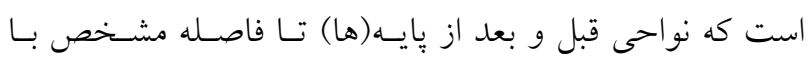

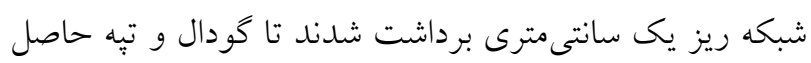

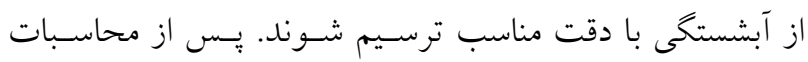

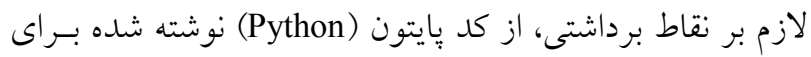

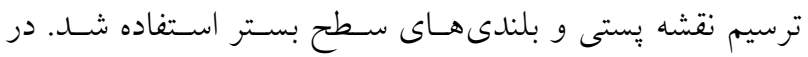




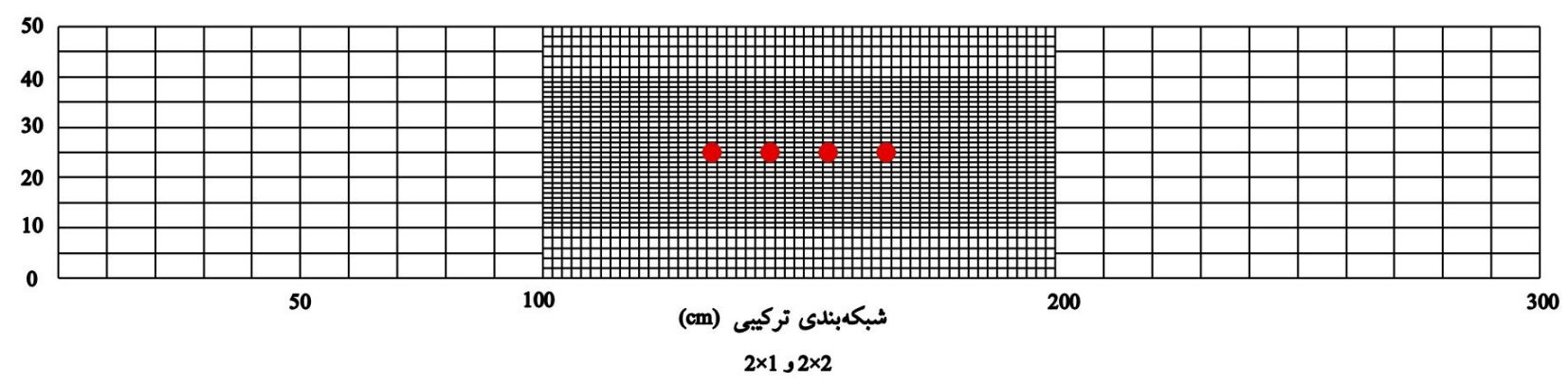

شكل f. شبكهبندى بستر رسوبات محل انجام آزمايش

جدول ا. ويزگگىهاى رسوبى و هيدروليكى آزمايشهاى آبشستى در اين يزوهش

\begin{tabular}{|c|c|c|c|c|c|c|c|c|c|c|c|c|c|}
\hline \multirow{2}{*}{\multicolumn{5}{|c|}{ ويزّكى هاى رسوبات استفاده در اين يزوهش }} & \multicolumn{9}{|c|}{ ويزگ گهاى هيدروليكى آزمايشهاى آبشستخى } \\
\hline & & & & & $\mathrm{h} / \mathrm{b}$ & $\mathrm{Fr}$ & $\mathrm{u} / \mathrm{u}_{\mathrm{c}}$ & $\begin{array}{c}\mathrm{u}_{\mathrm{c}} \\
(\mathrm{m} / \mathrm{s})\end{array}$ & $\begin{array}{l}\mathrm{u} *_{\mathrm{c}} \\
(\mathrm{m} / \mathrm{s})\end{array}$ & $\begin{array}{c}\mathrm{u} \\
(\mathrm{m} / \mathrm{s})\end{array}$ & $\begin{array}{c}\mathrm{h} \\
(\mathrm{cm})\end{array}$ & $\begin{array}{c}\mathrm{Q} \\
(1 / \mathrm{s})\end{array}$ & يارامتر \\
\hline $\begin{array}{c}\text { \% n } \\
\text { (تخلخل) }\end{array}$ & $\sigma_{\mathrm{g}}$ & $\begin{array}{c}\text { d* } \\
\text { (قطر بى بعد) }\end{array}$ & $\begin{array}{c}\mathrm{D}_{50} \\
(\mathrm{~mm})\end{array}$ & يار امتر & $T / T Q$ & $0 / 01$ & $\circ / 19$ & $\circ / \Delta \Delta$ & $0 / 04$ & $0 / 49$ & 9 & $r_{0}$ & شرايط 1 \\
\hline$r \Delta / \Delta$ & $1 / 4$ & 49 & r & مقدار & $r / \Delta$ & $0 / 40$ & $0 / 9$ & $0 / 09$ & $0 / 04$ & $\circ / \Delta r$ & 14 & $r \Delta$ & شرايط r \\
\hline
\end{tabular}

با توجه به اينكه در مطالعـه حاضـر در هـر دو شـرايط جريـان تعريف شده در جدول ا، ميزان h/b كمتر از 9 بوده، بنـابراين از

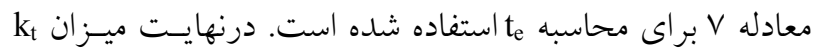

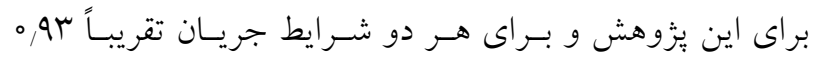

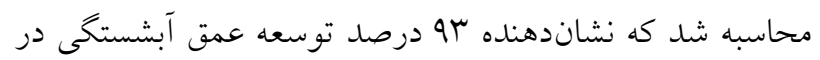
^ ساعت است. بنابر اين استفاده از اين روش نيـز همانــــ معيـار

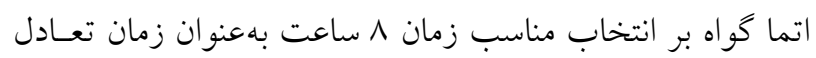

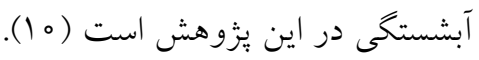

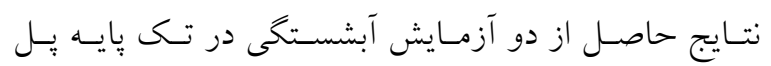

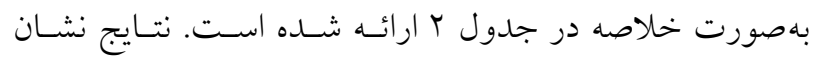

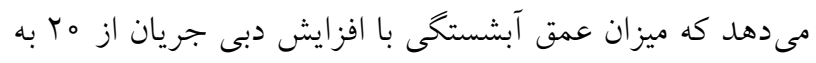

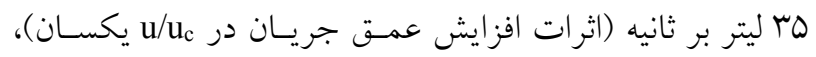
حدود 1/ درصد افزايش يافته است. علاوه بر اين، ابعاد كـودال

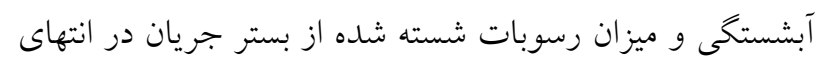

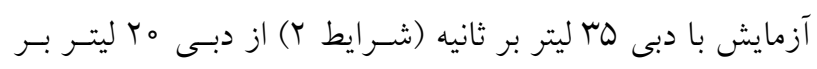

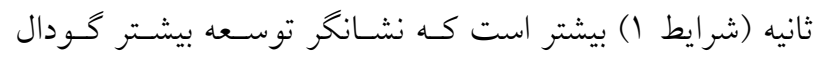

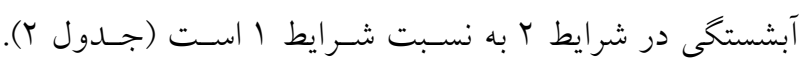

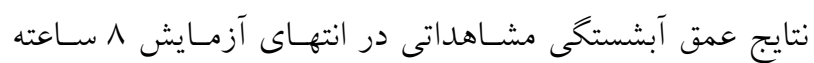

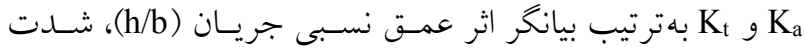
جريان (u/uluc)، اندازه نسبى ذرات رسـوب (b/d50)، شـكل بايسه، زاويه قراركيرى بايه نسـبت بـه جهـت جريـان و فــاكتور زمـان

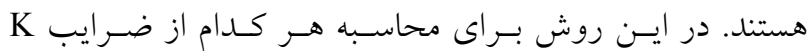
معادلهاى جداكانه تعريف شده است:

$\mathrm{d}_{\mathrm{s}} / \mathrm{b}=\mathrm{K}_{\mathrm{h}} \mathrm{K}_{\mathrm{I}} \mathrm{K}_{\mathrm{d}} \mathrm{K}_{\mathrm{s}} \mathrm{K}_{\alpha} \mathrm{K}_{\mathrm{t}}$

ملويل و كلمن معادله هـ را براى محاسبه فاكتور ka تحت عنسوان

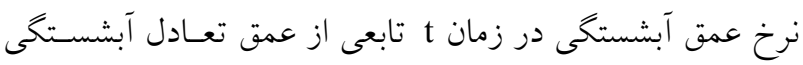

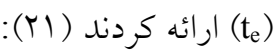

$\mathrm{K}_{\mathrm{t}}=\exp \left\{-0.03\left|\frac{\mathrm{u}_{\mathrm{c}}}{\mathrm{u}} \ln \left(\frac{\mathrm{t}}{\mathrm{t}_{\mathrm{e}}}\right)\right|^{1.6}\right\}$

در اين روش، بهمنظور محاسبه زمان تعادل آبشستگى در شرايط آب زلال از معادلات 9 و V استفاده مىشود: $\mathrm{t}_{\mathrm{e}}($ days $)=48.26\left(\frac{\mathrm{b}}{\mathrm{u}}\right)\left(\frac{\mathrm{u}}{\mathrm{u}_{\mathrm{c}}}-0.4\right) \frac{\mathrm{h}}{\mathrm{b}}>6 \frac{\mathrm{u}}{\mathrm{u}_{\mathrm{c}}}>0.4$

$\mathrm{t}_{\mathrm{e}}($ days $)=$

$30.89\left(\frac{\mathrm{b}}{\mathrm{u}}\right)\left(\frac{\mathrm{u}}{\mathrm{u}_{\mathrm{c}}}-0.4\right)\left(\frac{\mathrm{h}}{\mathrm{b}}\right)^{0.25} \quad \frac{\mathrm{h}}{\mathrm{b}}<6 \quad \frac{\mathrm{u}}{\mathrm{u}_{\mathrm{c}}}>0.4$ 
جدول r. مقايسه توسعه آبشستخى در دو آزمايش تك يايه در دو دبى جريان هب و هr ليتر بر ثانيه

\begin{tabular}{|c|c|c|c|c|c|}
\hline رسوبات شسته شده & $\begin{array}{c}\text { ابعاد كودال آبشستخى (x>y) } \\
(\mathrm{cm})\end{array}$ & زمانى كه يس از آن ds تغييرى ندارد & $\begin{array}{c}\mathrm{ds} t=8 \mathrm{~h} \\
(\mathrm{~cm})\end{array}$ & $\begin{array}{c}\mathrm{Q} \\
(1 / \mathrm{s})\end{array}$ & 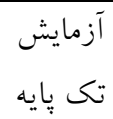 \\
\hline$r / T$ & TYXYG & kTo & $9 / 1$ & $r_{0}$ & شرايط 1 \\
\hline$\varphi / l$ & $\mu \circ \times \mu_{0}$ & $r q 0$ & $V / T$ & ro & شرايط r \\
\hline
\end{tabular}

جدول r. نتايج آزمايشگاهى گروه يايههاى با فاصله پايههاى متفاوت

\begin{tabular}{|c|c|c|c|c|c|c|c|c|c|c|c|}
\hline $\mathrm{ks}=\mathrm{ds} 1 / \mathrm{ds}$ & $\begin{array}{l}\mathrm{ds} 4 \\
(\mathrm{~cm})\end{array}$ & $\begin{array}{l}\text { ds3 } \\
\text { (cm) }\end{array}$ & $\begin{array}{l}\mathrm{ds} 2 \\
(\mathrm{~cm})\end{array}$ & $\begin{array}{l}\mathrm{ds} 1 \\
(\mathrm{~cm})\end{array}$ & $\begin{array}{c}\mathrm{ds} \\
(\mathrm{cm})\end{array}$ & $\mathrm{h} / \mathrm{b}$ & $\mathrm{u} / \mathrm{u}_{\mathrm{c}}$ & $\mathrm{s} / \mathrm{b}$ & $\begin{array}{c}\mathrm{s} \\
(\mathrm{cm})\end{array}$ & شرايط & شماره \\
\hline 1 & 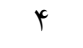 & 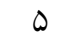 & $\Delta / r$ & $9 / 1$ & $9 / 1$ & $T / Y Q$ & $0 / 19$ & r & $\wedge$ & \multirow{3}{*}{ شرايط } & 1 \\
\hline$\circ / 9 V$ & $r / \Lambda$ & $\varphi / 4$ & $r / 0$ & $0 / 9$ & $9 / 1$ & $T / Y O$ & $0 / 19$ & $\mu$ & Ir & & r \\
\hline.$/ 9 \pi$ & $r / \mathcal{T}$ & $r / q$ & $r / 9$ & $\Delta / V$ & $9 / 1$ & $r / Y Q$ & $0 / 19$ & 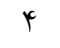 & 19 & & r \\
\hline $1 / 00$ & $\Delta / \omega$ & $9 / \mu$ & $9 / 4$ & $V / 9$ & $V / T$ & $\Gamma / Q$ & $\circ / 9$ & r & $\wedge$ & \multirow{3}{*}{ شرايط } & r \\
\hline $1 / \circ \mu$ & $4 / 1$ & $\Delta$ & $0 / 9$ & $V / 4$ & $V / T$ & $\Gamma / \Delta$ &.$/ 9$ & $\mu$ & Ir & & 0 \\
\hline $1 / \circ \mu$ & $\mu / \mu$ & k & $Q / Y$ & $V / T^{c}$ & $V / T$ & $\Gamma / \Delta$ & $0 / 9$ & r & 19 & & 9 \\
\hline
\end{tabular}

آبشستخى، گو نشان داد كه معيار h/b براى جريانهاى عميق بايد اصلاح شود (r) (I). اين محقق عنوان كرد كـه در مقـادير h/b>6 عمق آبشستخى مستقل از اثر افـزايش عمـق جريـان خواهد بود. با استفاده از تفاسير كو، اثر افزايش عمق جريان

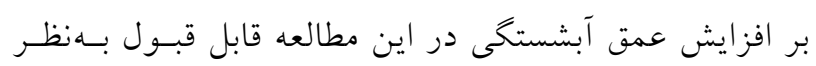

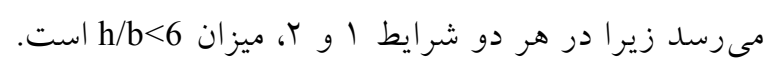

\section{r-r- آبشستخى در گروه يايه}

در اين بخش به بررسى تكامل زمانى عمق آبشستخى در تمـامى يايههاى موجود در يك كروه يايه يرداخته شده است. همانطور

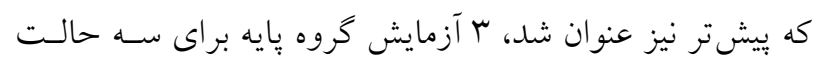

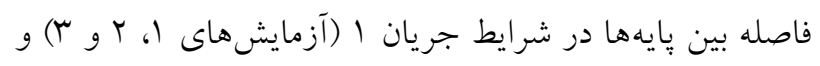

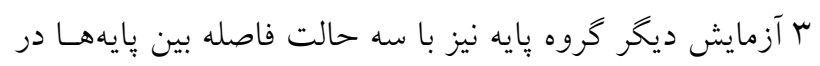

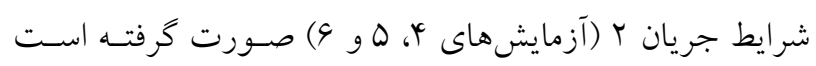

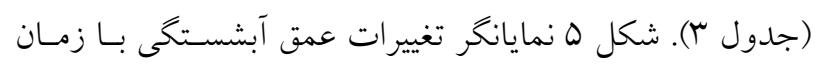

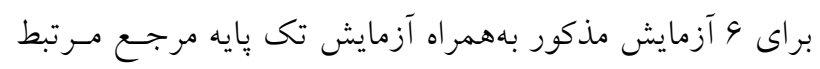

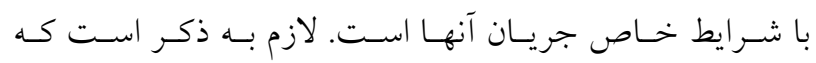

براى تكى يايه در ادامه براى تفسير نتايج آزمايشهاى گروه يُايـه استفاده شده است. براى مقايسـه نتـايج عمـق آبشسـتحى مشـاهداتى در دو

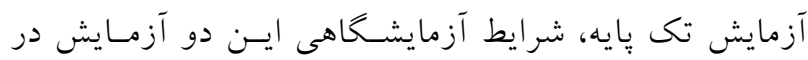

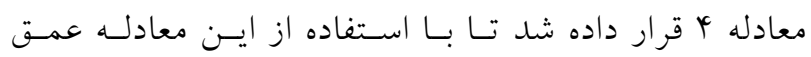

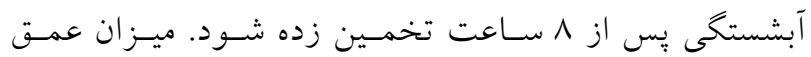
آبشستخى محاسبه شده توسط معادله ملويـل و كلمسن بـراى

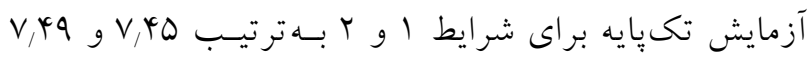
سانتى متر است. دليل عدم تغيير محسـوس در تخمسين عمـق آبشتخى براى شرايط ا و r توسط معادله أ، عدم لحاظ اثر

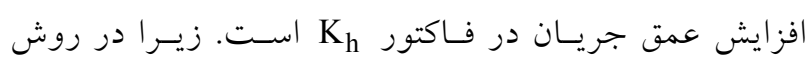
ملويـل و كلمـن، در مقــادير h/b>1.4، عمـق آبشسـتخى بــا افزايش عمق جريان، افزايش نخواهـــ يافـت (معيـار جريـان

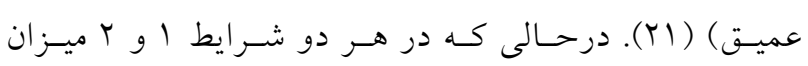

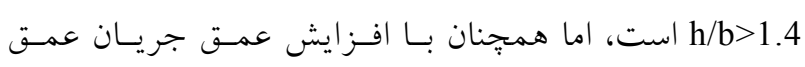
آبشستخى از / تحقيقات مشابهى براى تعيين اثرات عمق جريـان بـر ميـزان 


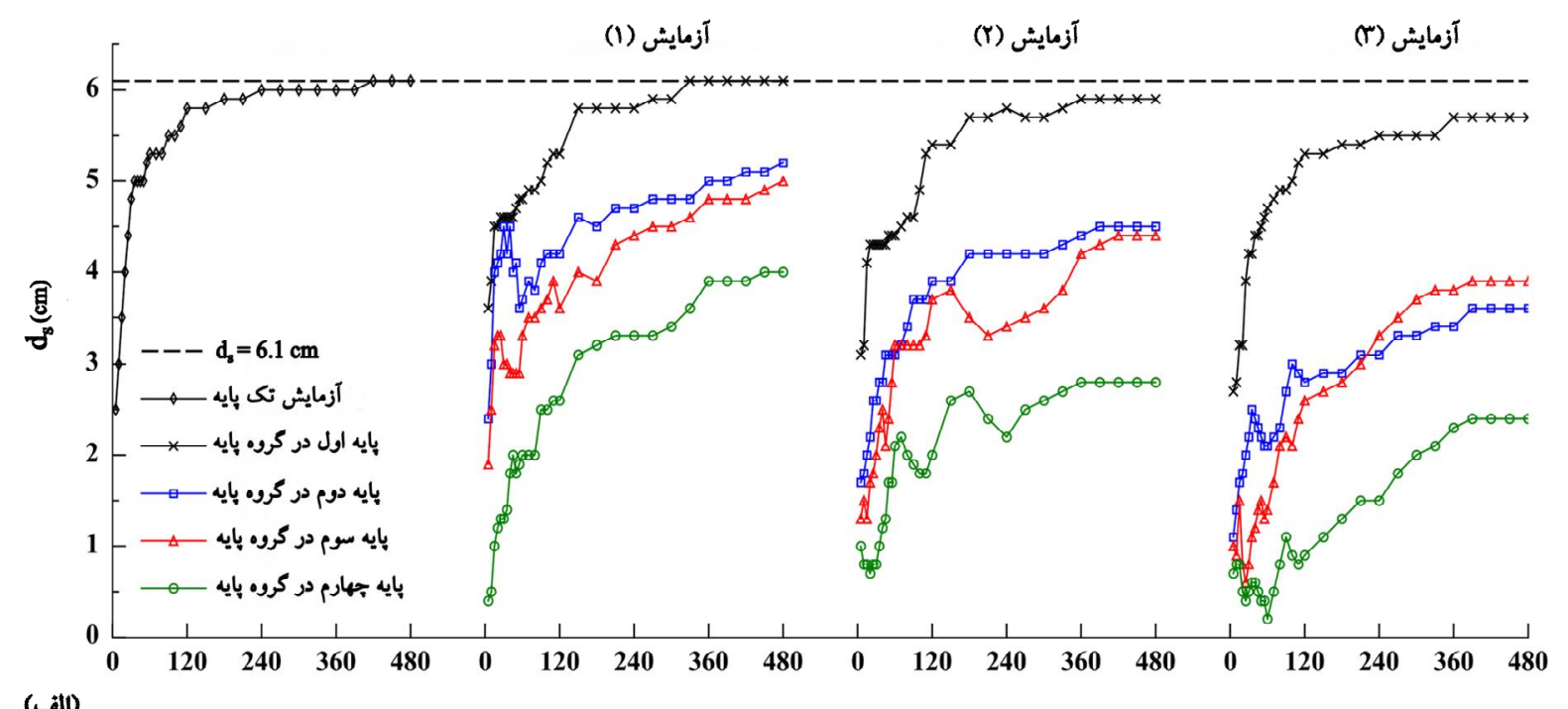
(a)

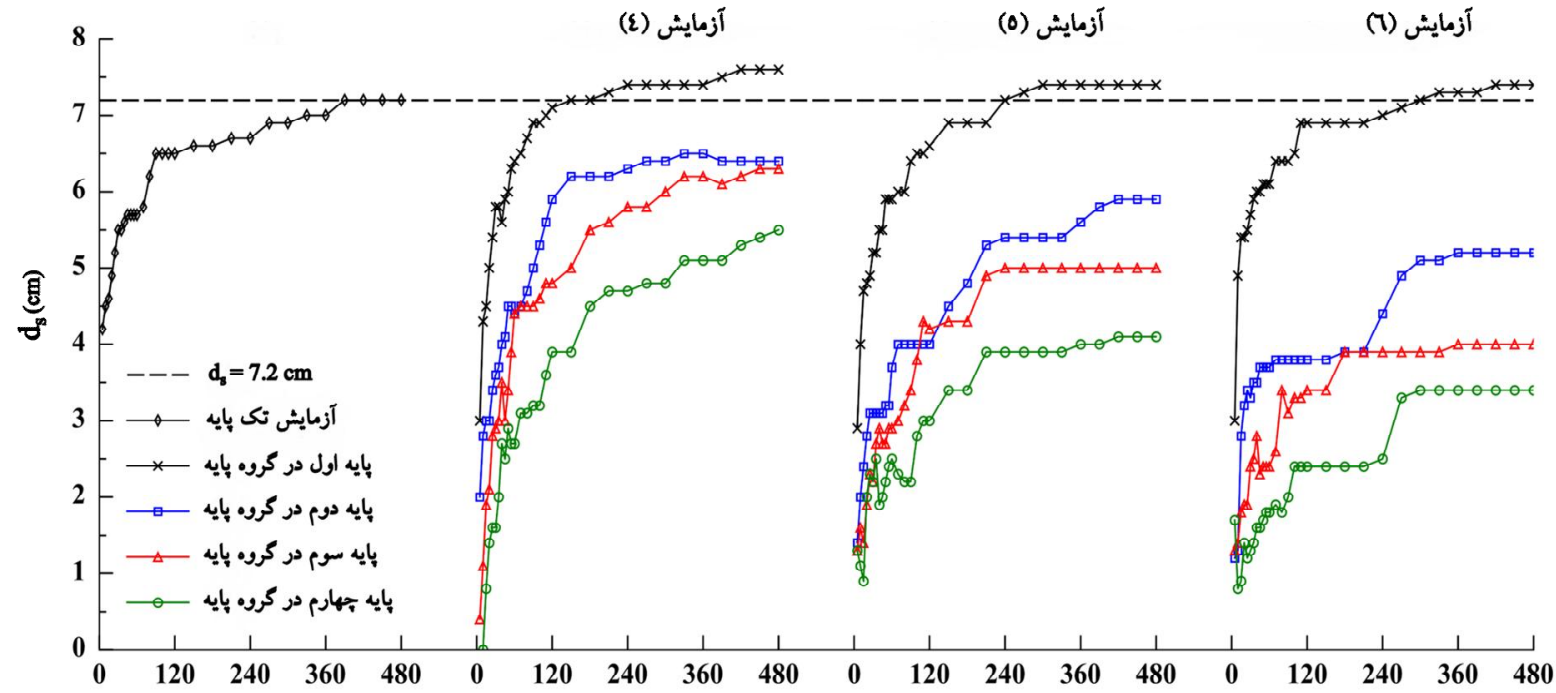
(ب)

زمان (دقيقه)

شكل ه. منحنى توسعه زمانى عمق آبشستخى در بايههاى موجود يك گروه بايه بههمراه تكى بايه مرجع آنها براى شرايط جريان:

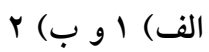

همانطور كه از شكل هه ملاحظـه مسىشـود، حسـاكثر عمـق

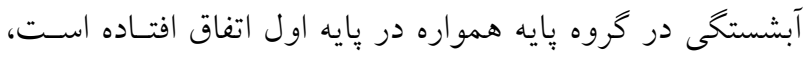
زيرا يايه اول بيشترين قدرت جريان رو بــه بـايين (downflow) را دريافت مىكند؛ درحالى كه در پايههـاى ؛ــاييندسـت ميـزان سرعت و قدرت جريـان بـه مراتـب كمتـر اسـت و دليـل ايـن

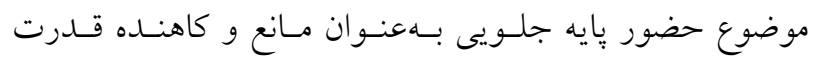

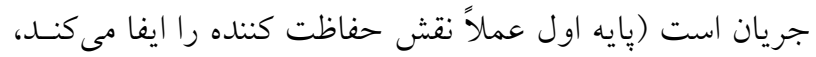

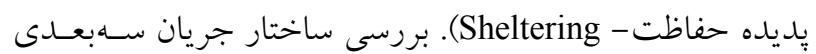

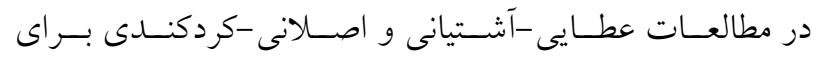

شماره گذارى بايهها در يـك گـروه بايسه از بالادسـت بـهسمت

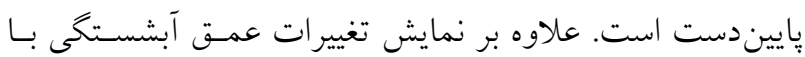

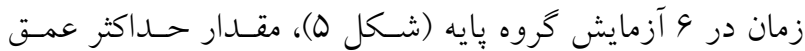

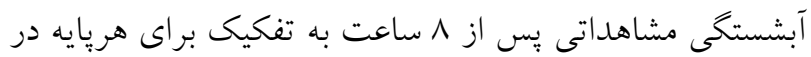

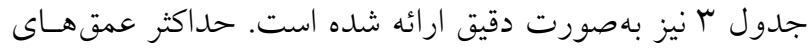

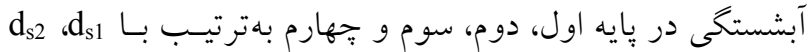

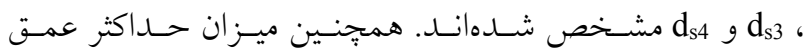

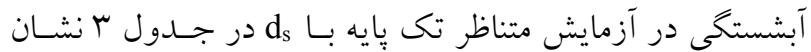

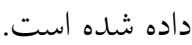



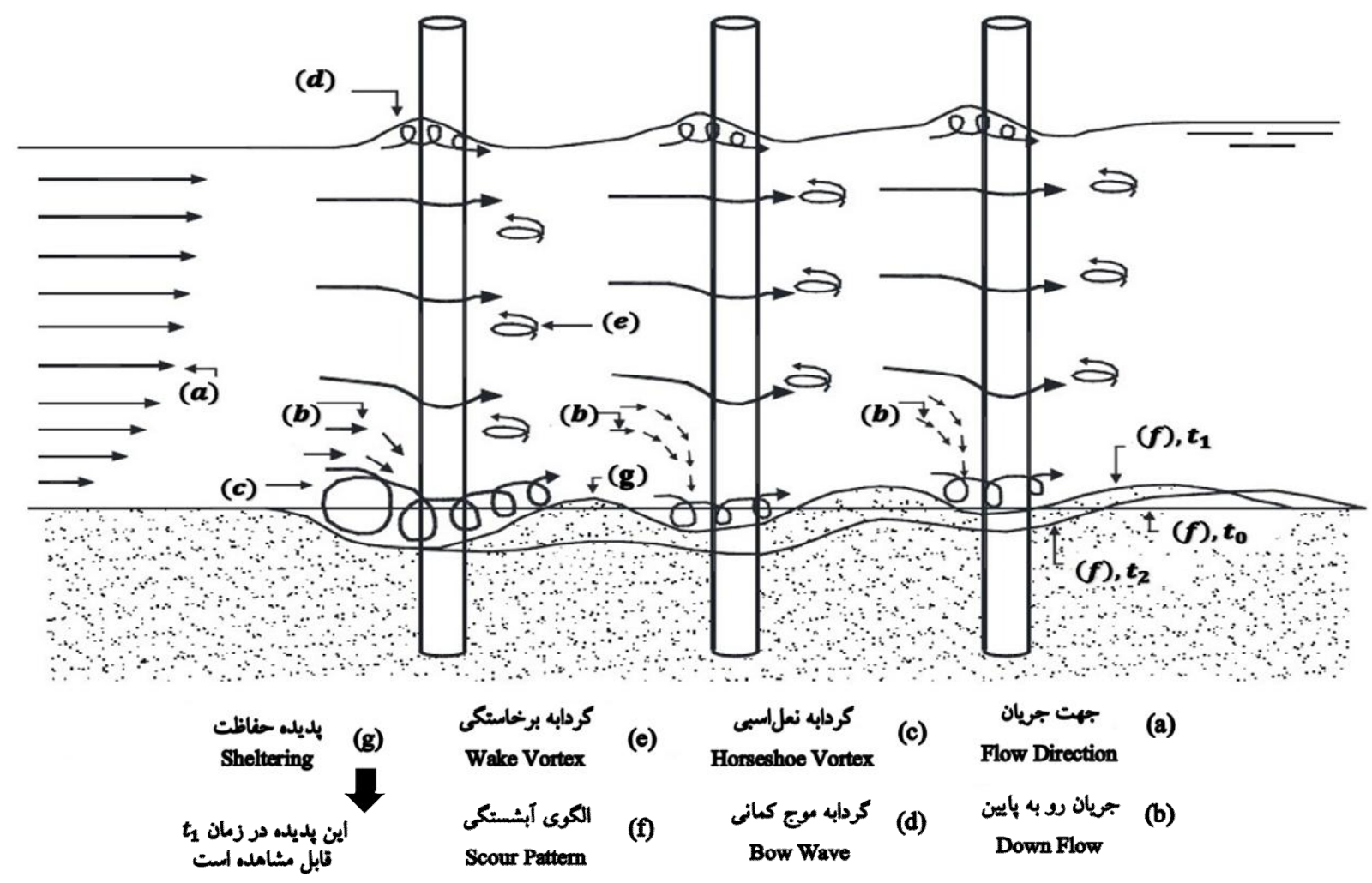

شكل צ. ساختار جريان و الكوى آبشستگى در اطراف يك گروه پايه تك ستونى با

كروه پايه مىشود (Y) (1). علاوه بر اين، مشـاهدات آزمايشـاهى

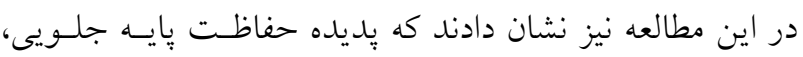
سبب تهنشين شدن رسوبات منتقل شده از اطراف پِيه بالادست

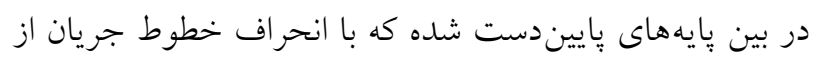

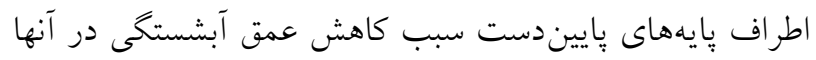

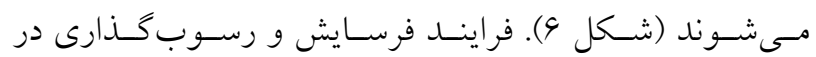

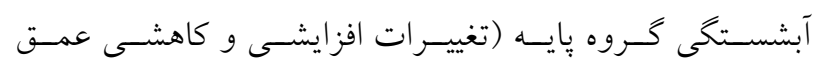

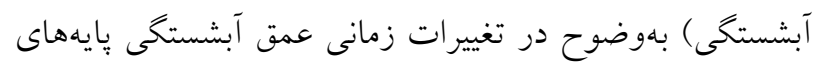

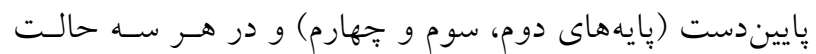
فاصله بين بايهها در شكل ه مشخص است، درحالى كه در بايه

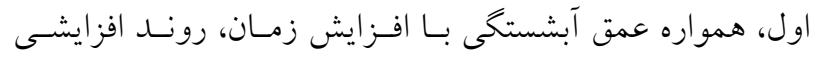

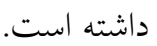
بنابر ميدان جريان توصيف شده در اطراف يـك گـروه پِيـهـ تكستونى مى توان نتيجه گرفت كه افزايش فاصله بـين بايـهـــا

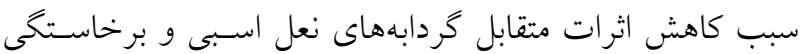

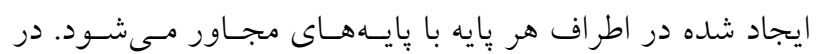

كرووه پِايسههـاى دوتـايى نشـان داده اسـت كـه سـرعت جريـان

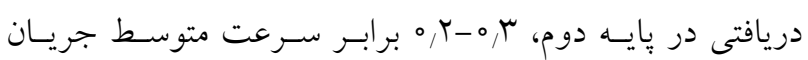

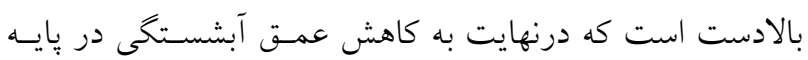

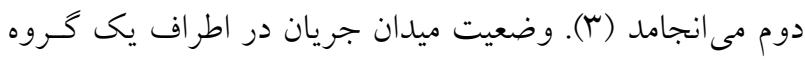

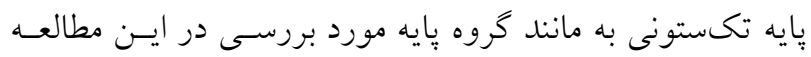

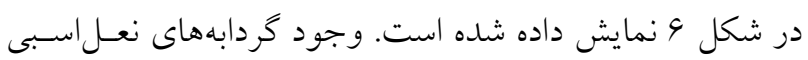

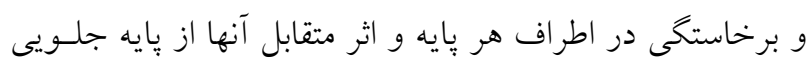
به بايه هاى عقبى سبب بيجيديدى ميدان جريان در اطراف خـروه

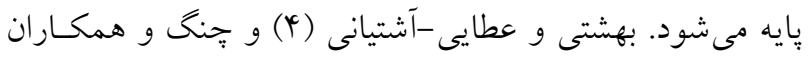
(9) در تحقيقاتى به بررسى ساختار جريان سـهبعـدى در گـروه پايهها يرداختند. نتايج آنها نشان داد كه با كاهش سرعت جريسان

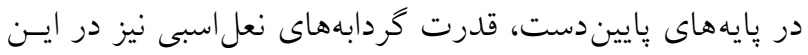

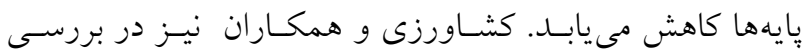

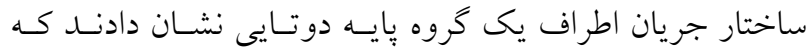

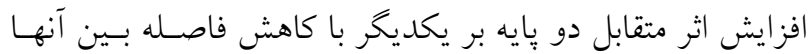

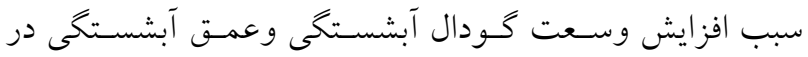



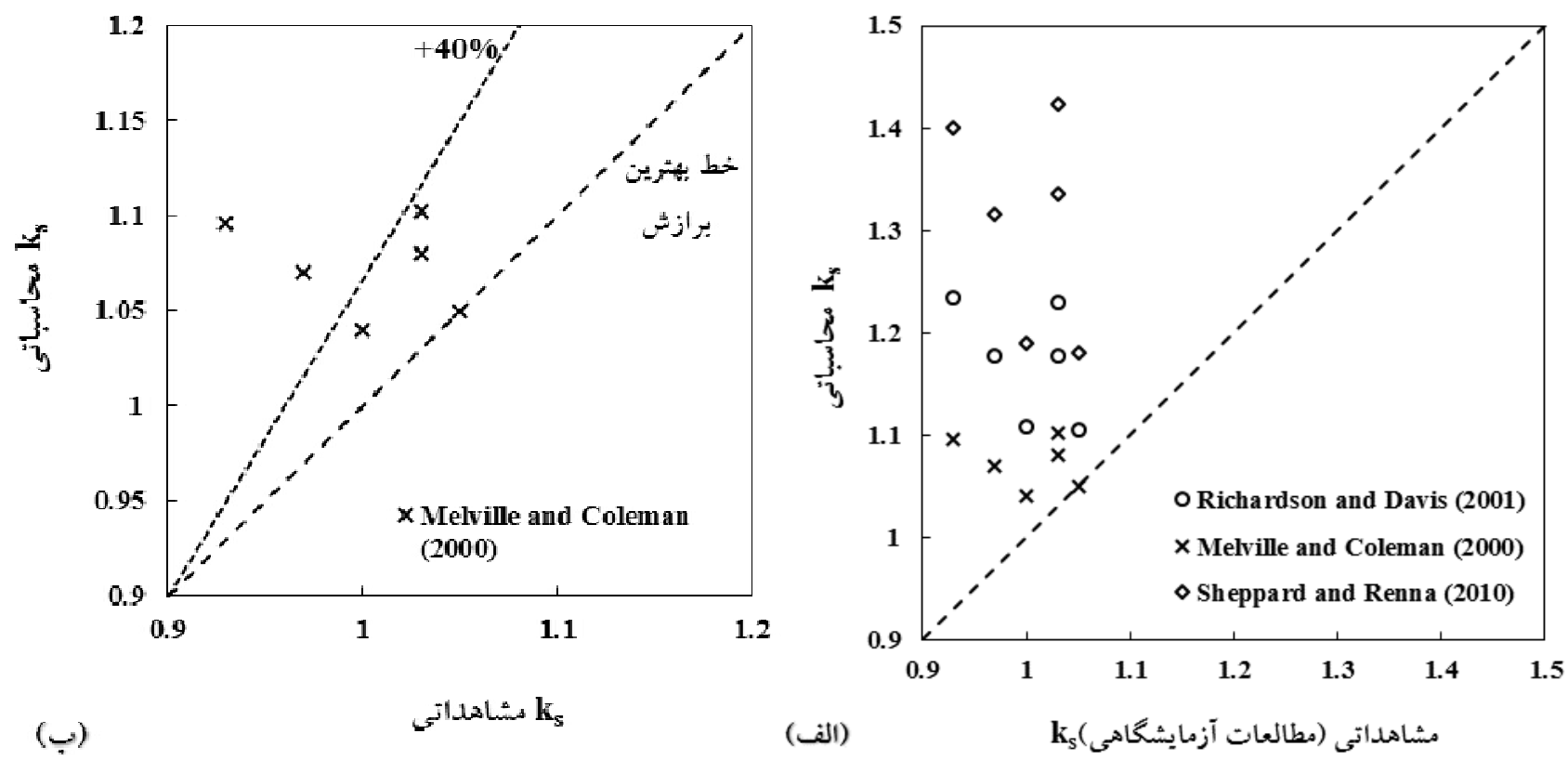

شكل V. مقايسه بين مقادير ks مشاهداتى (آزمايشخاهى) و محاسباتى به روشهاى مختلف در گروه پايه

مختلف توسط معادله ملويل و كلمن بهدست آمده است (YI). از دلايل اصلى بيشبرازش تخمينهاى ارائه شده بـراى نتـايج

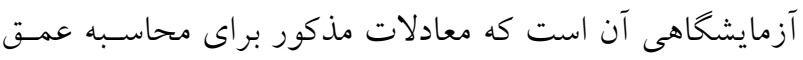

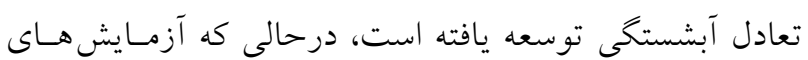
اين يزوهش در ^ ساعت بـه وضـعيت تعـادلى كامـل نرسـيده

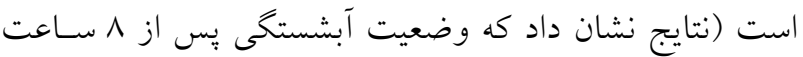

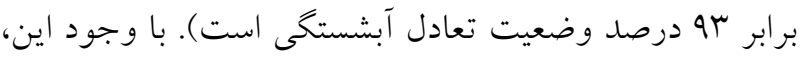

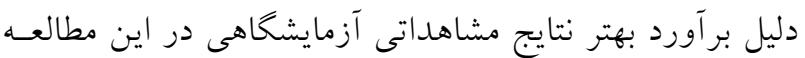

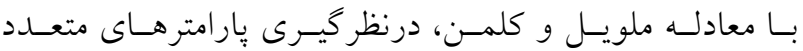

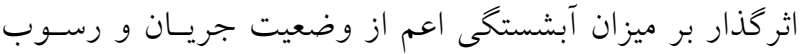
در اين معادله است. شكل V- ب نمايش دقيـق تـرى از نتـايج مشاهداتى و محاسباتى توسط معادله ملويل و كلمـن را نشـان

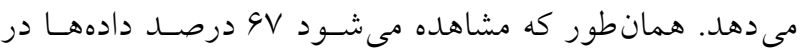
ناحيه ايجاد شده از خط بهتـرين بـرازش (خـط هو درجسه) و

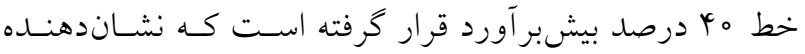

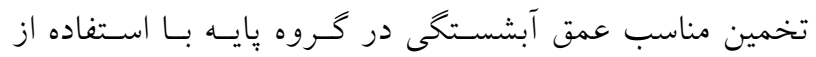

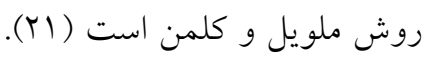

نتيجه، كاهش يافتن اثرات پِيهها بر يكديخر در يك گـروه بايسه سبب كاهش قدرت انتقال رسوبات بهويـزّه در پِايـهـــاى يـايين

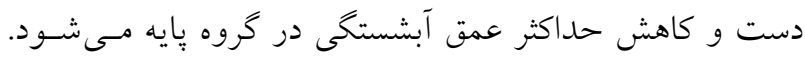

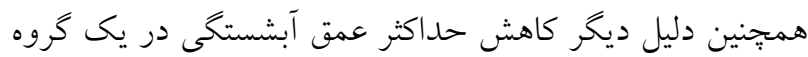

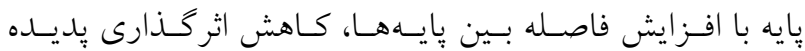
حفاظت است. بهمنظور مقايسه نتايج عمـقهــاى آبشستخكى بـا مطالعـات

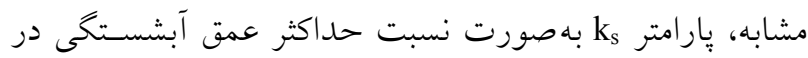

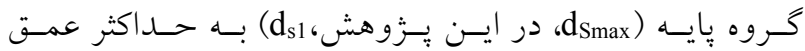

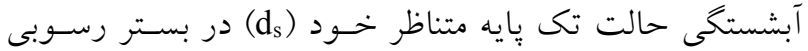
يكسان و وضعيت جريان مشابه تعريف شده است (جدول ؟).

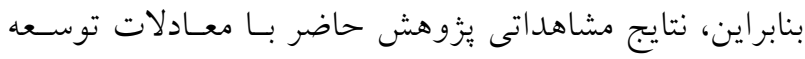

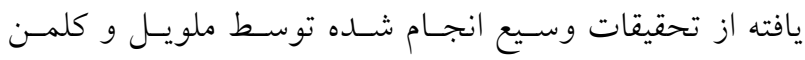

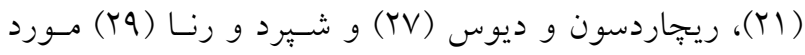

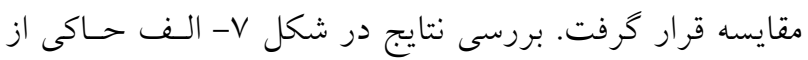

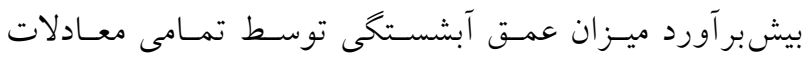

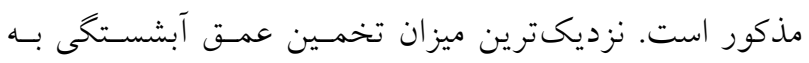

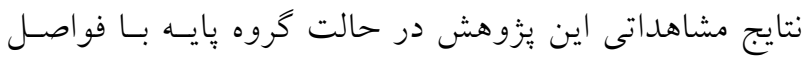



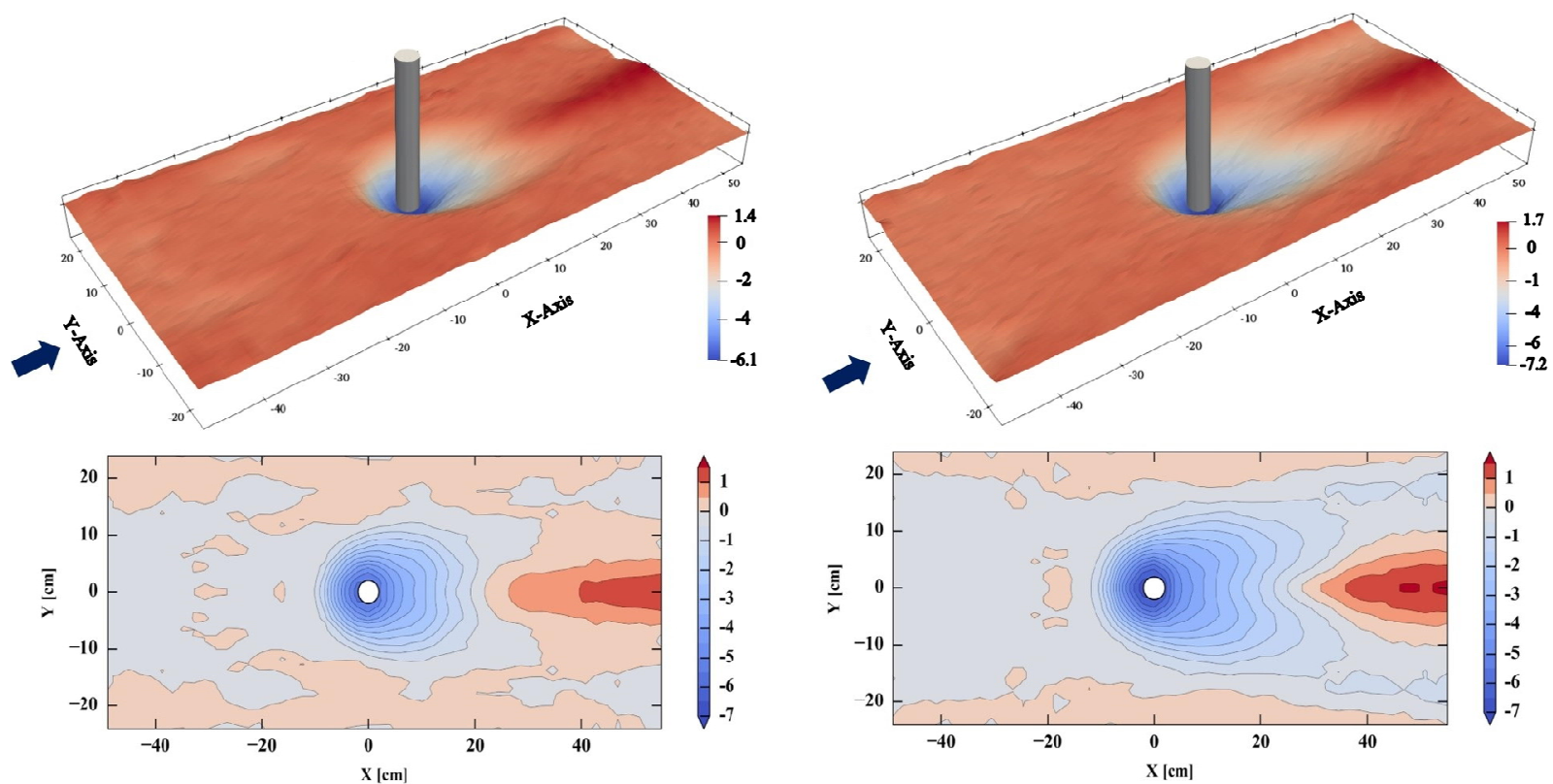

دبى •اليز برثاني (نرإيط )

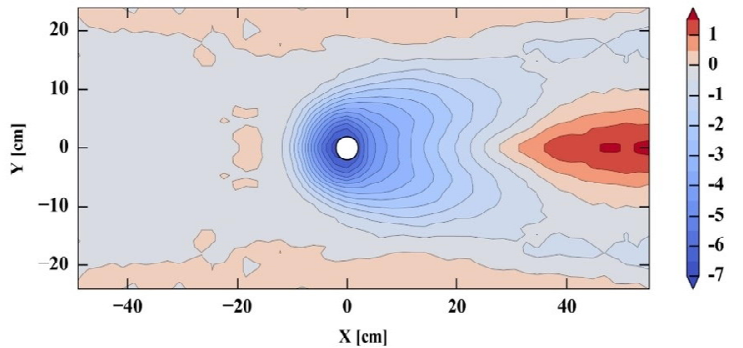

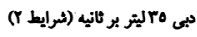

شكل ^. نمايش بستى و بلندى سطح بستر به همراه خطوط تراز براى دو آزمايش تكىيايه

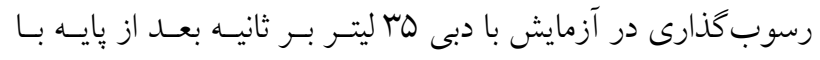

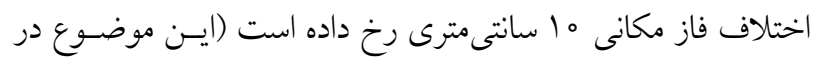

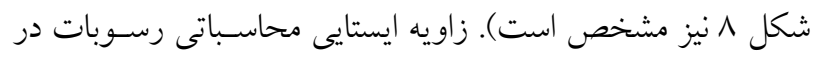

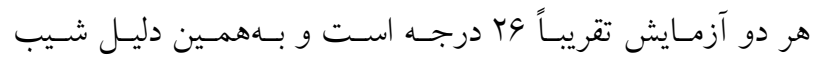
قرارگيرى رسوبات در بالادست بايه تقريباً مشابه است.

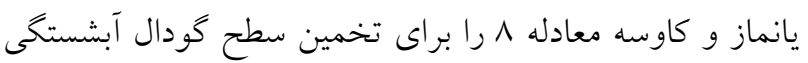

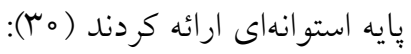

$$
\mathrm{A}_{*}=\frac{\mathrm{A}}{\mathrm{A}_{\mathrm{p}}}=2.904\left(\mathrm{~T}_{\mathrm{s}}\right)^{0.399}
$$

در اين معادله، A سطح كودال آبشتتىى بر حسـب سـانتى متـر

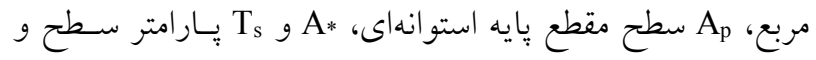
زمان بىبعد تعريف شده در معادله ^ هستند. در اين معادله، بهورت م جگالى رسوبات و آب هستند. مقايسه سطح گودال آبشستخى تخمينى توسط معادله ^ با ابعاد محاسباتى طول و عرض كو كودال

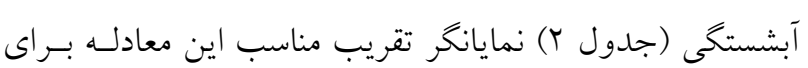

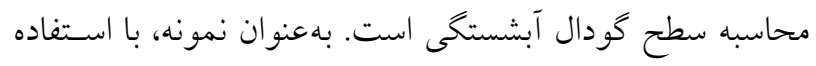

بستى و بلندى گودال آبشستخى

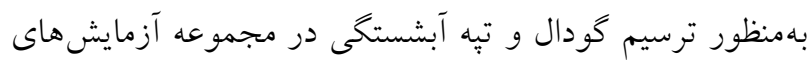

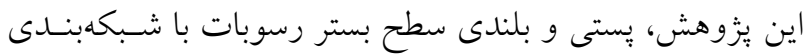

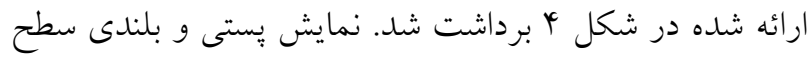

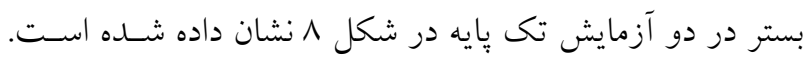
همانطور كه در اين شكل ديده مى شود، ميزان وسـت كَودال

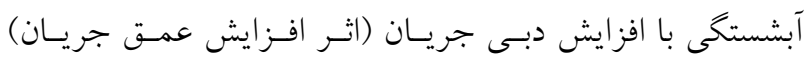

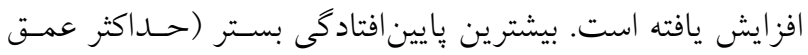

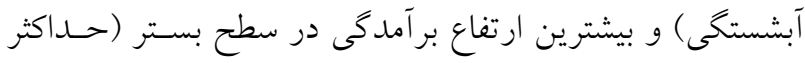

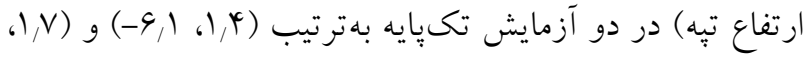

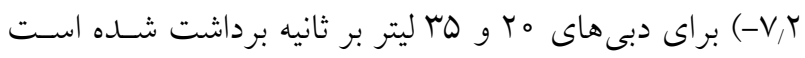
كه بهوضوح اثرات افزايش دبى و عمق جريان در شرايط يكسان

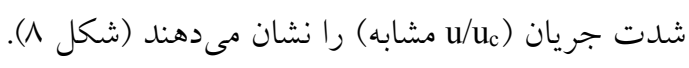

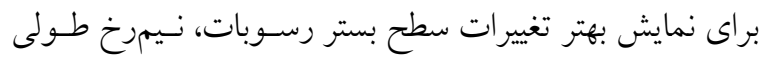

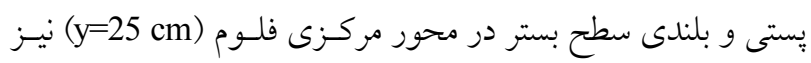

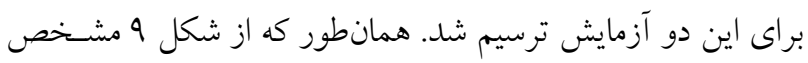

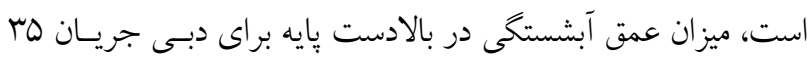

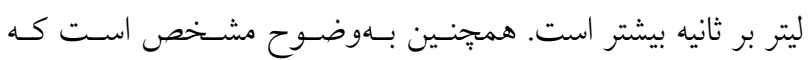




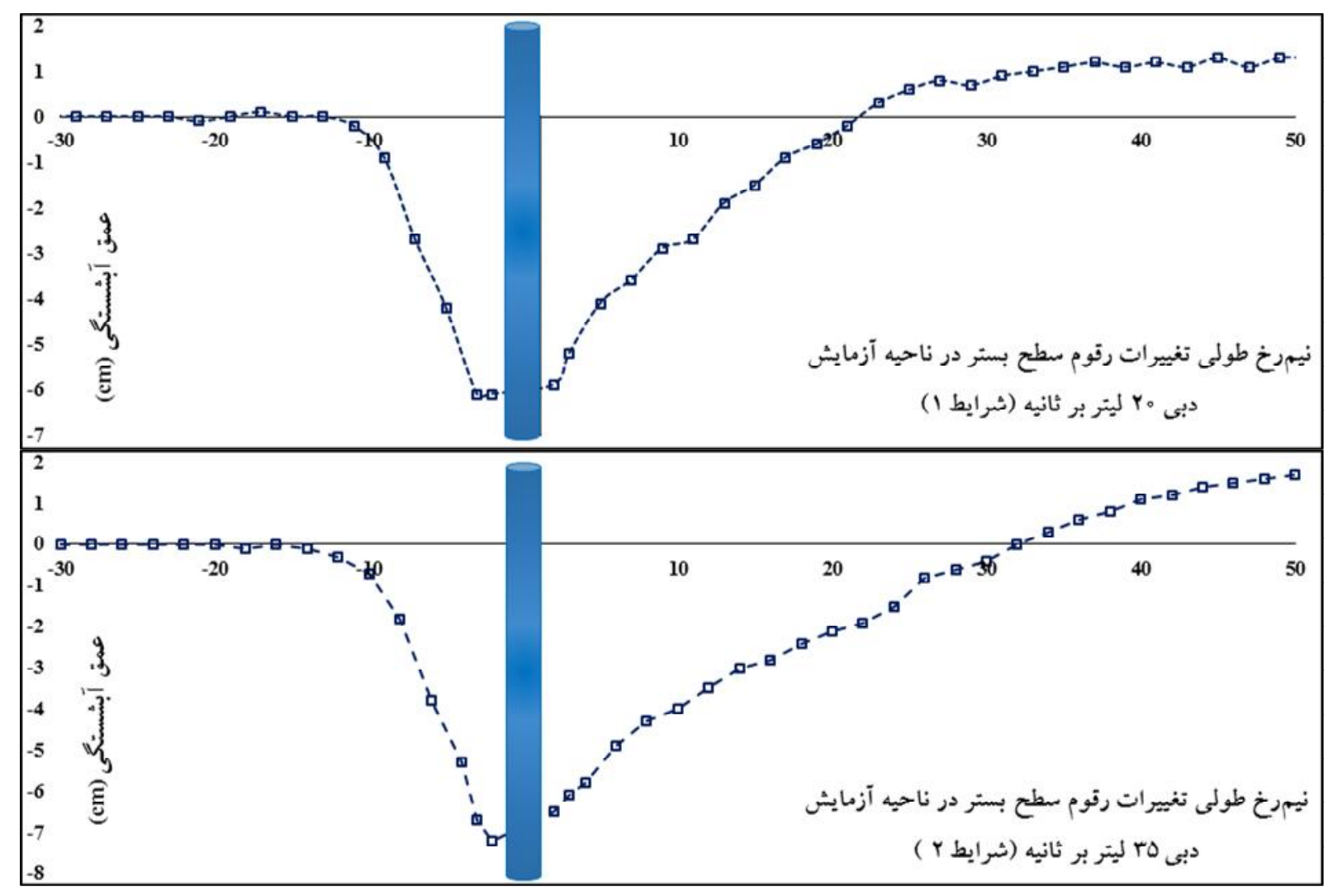

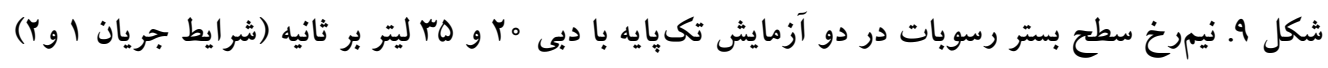

انجام شده در اين يُزوهش نشانكر آن است كه در گروه بايههاى

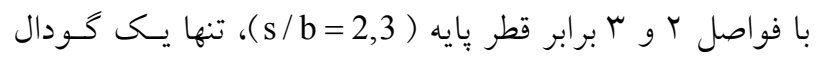

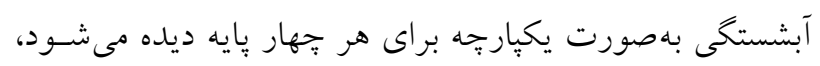

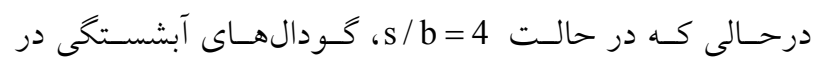
اطراف هر بايه بهصورت مجزا تشكيل شده است و يكى خـودال

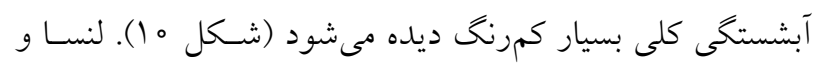

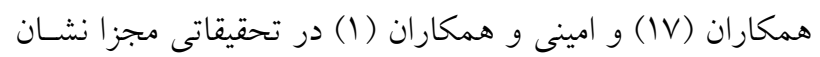

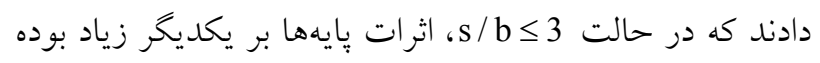

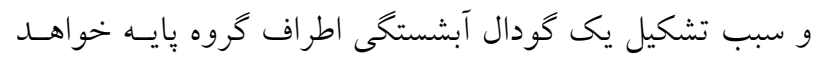

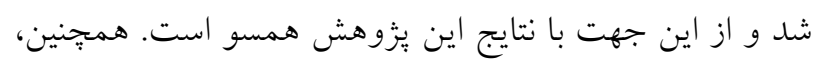

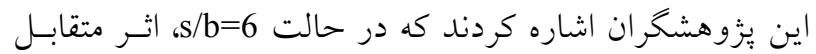

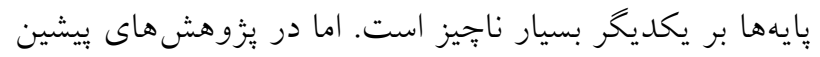

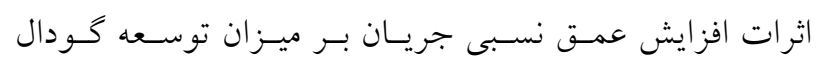

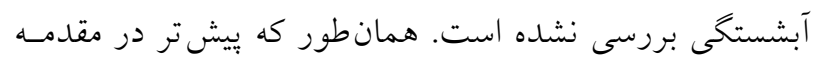

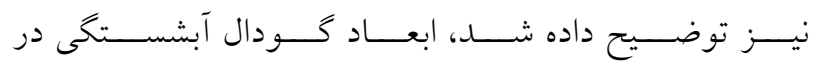

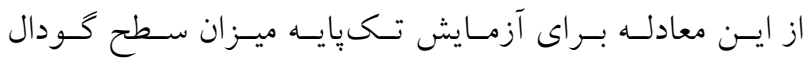

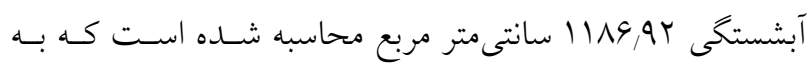
ابعاد طول و عرض مشاهداتى در آزمايش دبى ها ليتر بـر ثانيـه

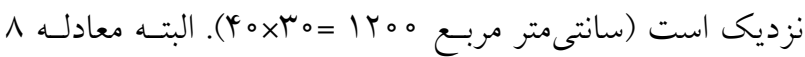

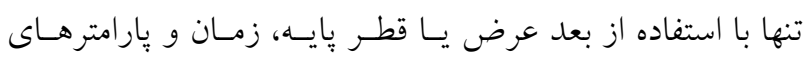

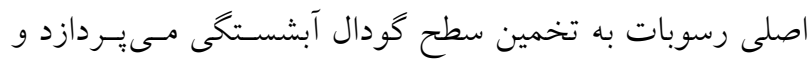
ويزگى هاى هيدروديناميكى جريان را درنظر نمى گيرد.

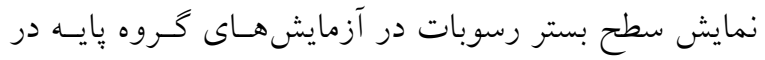
شكل ه 1 قابل مشاهده است. شكل گودال آبشستخى در حالـت

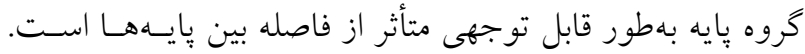
همانطور كه بيشتر نيز بيان شد، با افزايش فاصله بـين بايسههـا ميزان اثر كذارى بايهها بر يكديخر كمتر شده و با كـاهش يـافتن بئن

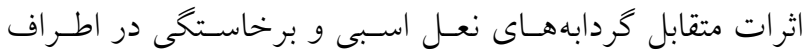

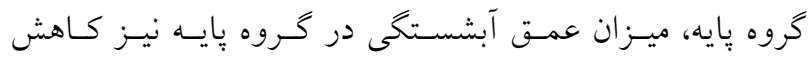

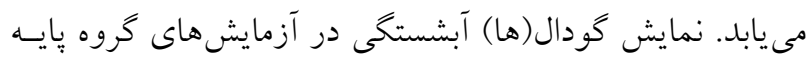



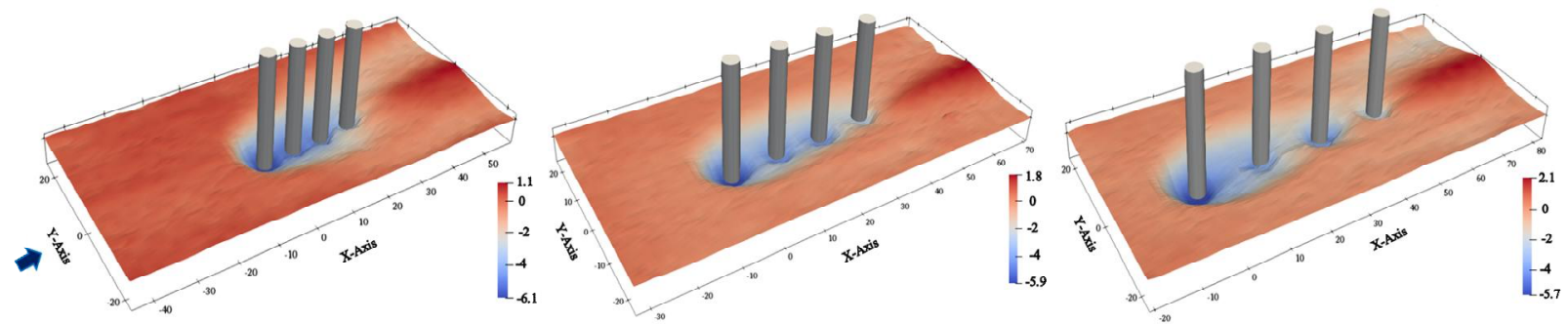

آزمايش 1

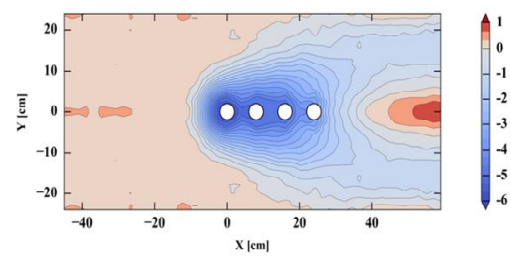

آزمايش r

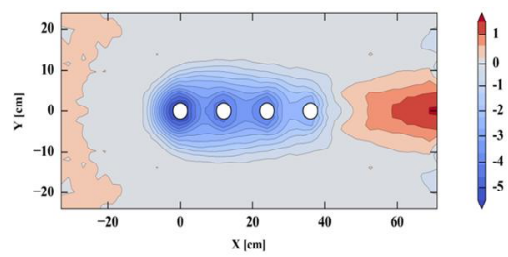

آزمايش r
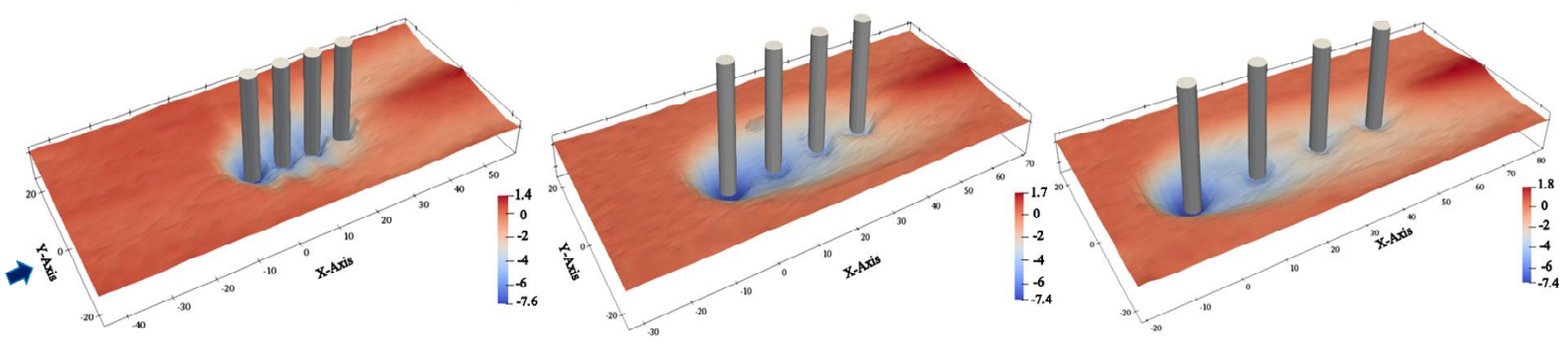

¿ آن آنمايش

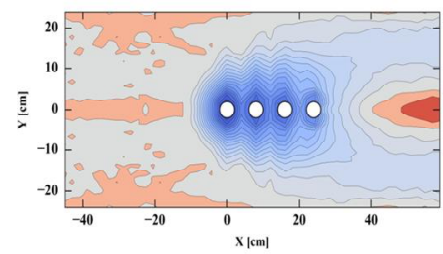

آرمايش
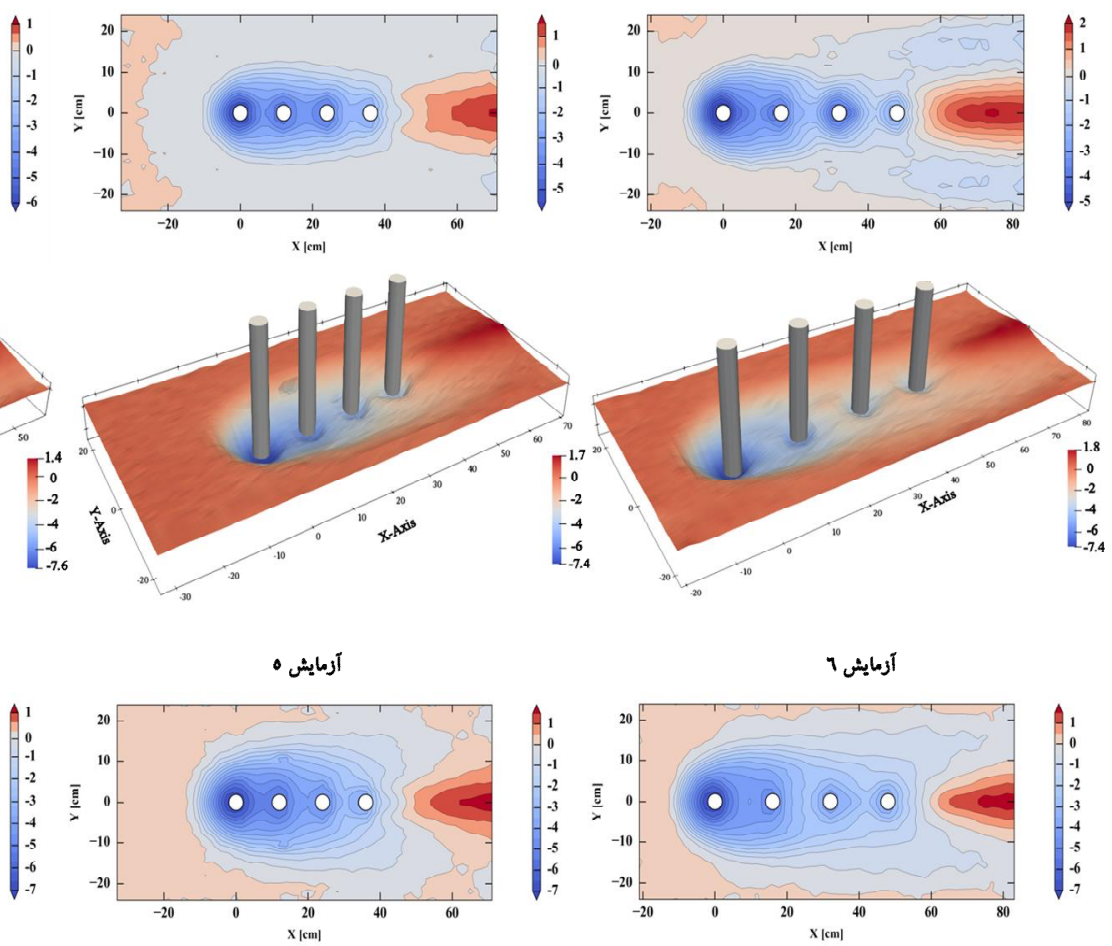

شكل ه ا. نمايش بِتى و بلندى سطح بستر بههمراه خطوط تراز براى 9 آزمايش گروه يايه

\section{نتيجه گيرى}

مجموعه آزمايش هاى اين يزّوهش بهمنظور بررسى اثرات فاصله

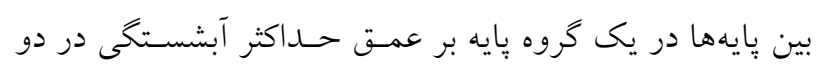

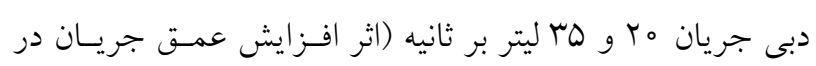

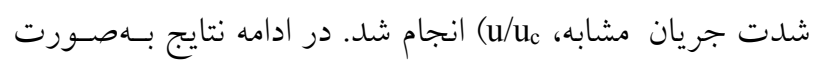
موردى بيان شدهاند. ا- بررسى نتايج نمودار توسعه آبشستكى با زمان نشـان داد كـهـ

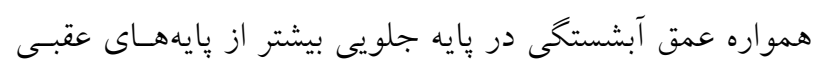

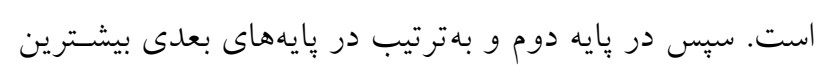

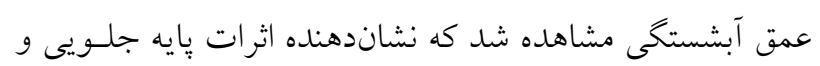

انتخاب روش كنترل و كاهش آبشستخى بسيار تأثير گذار اسـت.

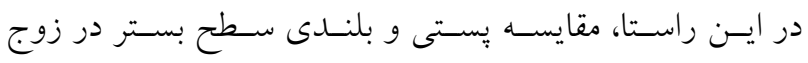

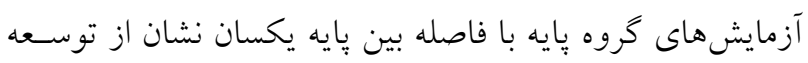

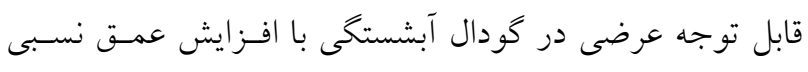

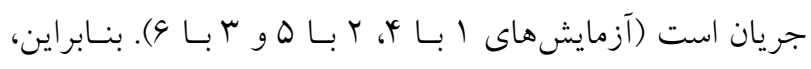

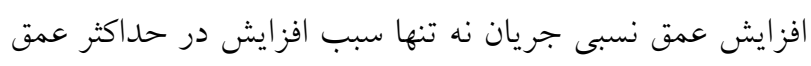

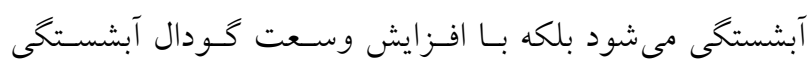

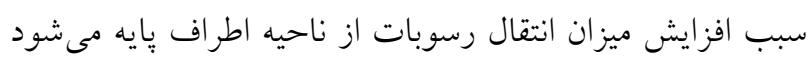

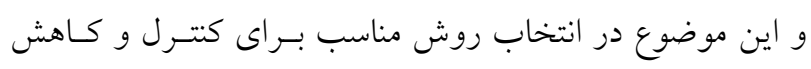
ميزان آبشستخى اثر مستقيم دارد. 


$$
\begin{aligned}
& \text { بر يكديخر، كودالهاى آبشستخى بهصورت مجزا در اطراف هـر } \\
& \text { نقش آن در كاهش سرعت و قدرت جريـان اسـت ( } \\
& \text { يايه ديلده مىشونل. } \\
& .\left(d_{\mathrm{s} 3}>\mathrm{d}_{\mathrm{s} 4}\right.
\end{aligned}
$$

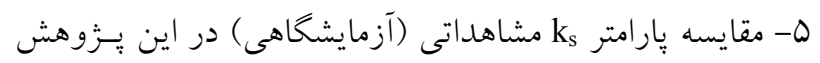

$$
\begin{aligned}
& \text { ז- حداكثر عمق آبشستخى در خـروه يّايسههـاى مـورد آزمـايش } \\
& \text { با مقادير محاسباتى با معادلات توسعه يافتـه (ملويـل و كلمـن)، }
\end{aligned}
$$

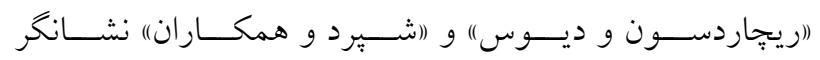

$$
\begin{aligned}
& \text { بيشبرآورد ميزان عمق آبشستـى توسط معـادلات مـذكور در }
\end{aligned}
$$

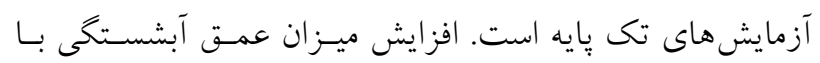

$$
\begin{aligned}
& \text { ضريب أ إبهعنوان ضريب اطمينان براى دستيابى به مرز بالايى } \\
& \text { شكل V- ب (توافق مناسب با نتايج روش ملويل و كلمن) براى } \\
& \text { مطالعات آينده و طراحى مطمئن بيى سازه يايه يل منطقى بهنظـ }
\end{aligned}
$$

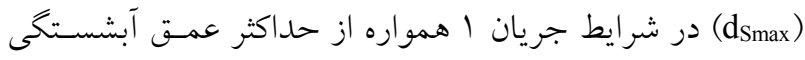

$$
\begin{aligned}
& \text { تك يايه متناظر خود (ds) كمتر است (d) } \\
& \text { در شرايط جريان r، اين مورد بـرعكس (d } \\
& \text { نشانگر اثرات افزايش دبى و عمق جريان در گروه يايه است. } \\
& \text { ب- بيشترين ميزان عمـق آبشسـتخى در خـروههـاى بايـهـ مـورد } \\
& \text { بررسى و در هر دو شرايط جريان ا و ب (دبى مب و هـ ليتر بـر } \\
& \text { ثانيه) در حالت s/b=6 رخ داده است و با افزايش ميـزان فاصـله } \\
& \text { بين بايهها، حداكثر عمق آبشستخى كاهش يافته است. }
\end{aligned}
$$

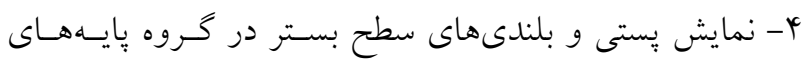

$$
\begin{aligned}
& \text { مختلف نشان داد كه با افزايش s/b و كاهش اثرات متقابل هايهها }
\end{aligned}
$$

\section{منابع مورد استفاده}

1. Amini, A., B. W. Melville, T. M. Ali and A. H. Ghazali. 2012. Clear-water local scour around pile groups in shallow-water flow. Journal of Hydraulic Engineering 138(2): 177-185.

2. Ataie-Ashtiani, B. and A. A. Beheshti. 2006. Experimental investigation of clear-water local scour at pile groups. Journal of Hydraulic Engineering 132(10): 1100-1104.

3. Ataie-Ashtiani, B. and A. Aslani-Kordkandi. 2013. Flow field around single and tandem piers. Flow, Turbulence and Combustion 90(3): 471-490.

4. Beheshti, A. A. and B. Ataie Ashtiani. 2010. Experimental study of three-dimensional flow field around a complex bridge pier. Journal of Engineering Mechanics 136(2): 143-154.

5. Breusers, H. N. C., G. Nicollet and H. W. Shen. 1977. Local scour around cylindrical piers. Journal of Hydraulic Research 15(3): 211-252.

6. Chang, W. Y., G. Constantinescu, H. C. Lien, W. F. Tsai, J. S. Lai and C. H. Loh. 2013. Flow structure around bridge piers of varying geometrical complexity. Journal of Hydraulic Engineering 139(8): 812-826.

7. Diab, R., O. Link and U. Zanke. 2010. Geometry of developing and equilibrium scour holes at bridge piers in gravel. Canadian Journal of Civil Engineering 37(4): 544-552.

8. Elhimer, M., G. Harran, Y. Hoarau, S. Cazin, M. Marchal and M. Braza. 2016. Coherent and turbulent processes in the bistable regime around a tandem of cylinders including reattached flow dynamics by means of high-speed PIV. Journal of Fluids and Structures 60: 62-79.

9. Eshaghian, M., S. Gohari and S. Okhravi. 2020. Single bridge pier scour in uniform and non-uniform sediment beds under steady and unsteady flow. Journal of Hydraulics 14(4): 19-33. (In Farsi)

10. Ettema, R. 1980. Scour at bridge piers. Ph.D. Thesis, Department of Civil Engineering, University of Auckland.

11. Gaudio, R., A. Tafarojnoruz and S. De Bartolo. 2013. Sensitivity analysis of bridge pier scour depth predictive formulae. Journal of Hydroinformatics 15(3): 939-951.

12. Guo, J. 2012. Pier scour in clear water for sediment mixtures. Journal of Hydraulic Research 50(1): 18-27.

13. Heidarpour, M., H. Afzalimehr and E. Izadinia. 2010. Reduction of local scour around bridge pier groups using collars. International Journal of Sediment Research 25(4): 411-422.

14. Keshavarzi, A., H. Hamidifar and L. Khajehnouri. 2019. Mean flow structure and local scour around single and twocolumn bridge piers. Irrigation Sciences and Engineering 42(4): 75-90. (In Farsi)

15. Keykhee, M., M. Heidarpour and S. F. Mousavi. 2009. Investigation of riprap pattern in the vicinity of bridge piers group. Journal of Water and Soil Science 13(49): 13-29. (In Farsi) 
16. Lança, R. 2013. Clear-water scour at single piers and pile groups. Ph.D. Thesis. Department of Engineering, Universidade Da Beira Interior.

17. Lança, R., C. Fael, R. Maia, J. P. Pêgo and A. H. Cardoso. 2013. Clear-water scour at pile groups. Journal of Hydraulic Engineering 139(10): 1089-1098.

18. Laursen, E. M. and A. Toch. 1956. Scour Around Bridge Piers and Abutments (Vol. 4). Ames, IA: Iowa Highway Research Board, Bureau of Public Roads, Iowa.

19. Melville, B. W. and A. J. Sutherland. 1988. Design method for local scour at bridge piers. Journal of Hydraulic Engineering 114(10): 1210-1226.

20. Melville, B. W. and Y. M. Chiew. 1999. Time scale for local scour at bridge piers. Journal of Hydraulic Engineering 125(1): 59-65.

21. Melville, B. W. and S. E. Coleman. 2000. Bridge Scour. Water Resources Publication. LLC, Denver.

22. Memar, S., M. Zounemat Kermani, M. Rahimpour, A. A. Beheshti and A. J. Schleiss. 2019. An investigation on the impacts of the skew angle on two bridge piers with respect to the flow direction on the equilibrium scour depth at the piers front. Journal of Hydraulics 14(1): 107-121. (In Farsi)

23. Mia, M. F. and H. Nago. 2003. Design method of time-dependent local scour at circular bridge pier. Journal of Hydraulic Engineering 129(6): 420-427.

24. Moreno, M., R. Maia and L. Couto. 2016. Prediction of equilibrium local scour depth at complex bridge piers. Journal of Hydraulic Engineering 142(11): 04016045.

25. Okhravi, S. and S. Gohari. 2020. Form friction factor of armored river beds. Canadian Journal of Civil Engineering 47(11): 1238-1248.

26. Raudkivi, A. J. and R. Ettema. 1985. Scour at cylindrical bridge piers in armored beds. Journal of Hydraulic Engineering 111(4): 713-731.

27. Richardson, E. V. and S. R. Davis. 2001. Evaluating Scour at Bridges: Hydraulic engineering circular No. 18. (HEC-18). Rep. Rep. No. FHWA NHI 01-001, Federal Highway Administration, Washington. DC.

28. Salim, M. and J. S. Jones. 1998. Scour around exposed pile foundations. In North American water and environment congress \& destructive water, Reston.

29. Sheppard, D. M. and R. Renna. 2010. Bridge scour manual. Florida Department of Transportation, Tallahassee, FL.

30. Yanmaz, A. M. and Ö. Köse. 2007. Surface characteristics of scouring at bridge elements. Turkish Journal of Engineering and Environmental Sciences 31(2): 127-134. 


\title{
Local Scour at Single Column Arrangement of Bridge Piles Group
}

\author{
S. S. Okhravi and S.Gohari ${ }^{*}$
}

(Received: February 20-2020; Accepted: June 29-2020)

\begin{abstract}
In regard to wide piers, the pile group rather than single pile is used frequently to bear the loading of the structure in a particular arrangement; piles group composed of only one column of piles in the flow direction has a great effect on supporting the bridge deck. In this study, local scour at a single column arrangement of the piles group made up of four rows of piles characterized by different piles spacing was studied for clear-water conditions with two flow discharges of 20 and 35 1/s (the effect of increasing the flow depth with the same flow intensity). The results indicated that an increase in the flow depth not only greatly enhanced the scour depth and the width of the scour hole. Besides, the investigation of the relative flow depth on scour extent showed the need for revision in deep water conditions, as reported in the literature. The results of the pile group experiments revealed the noticeable impacts of piles spacing on the local scour. The bigger pile spacing caused a feeble interaction of wake-horseshoe vortices, leading to a decrease of the scour depth; the separate view of the scour holes was generated at individual piles. Finally, the results were compared with commonly used comprehensive models. The findings of this study can be applied for the appropriate selection and positioning for the countermeasure of the scour at bridge piers.
\end{abstract}

Keywords: Local scour, Pile group, Scour depth, Time, Piles spacing

1. Department of Water Engineering, College of Agriculture, Bu-Ali Sina University, Hamadan, Iran

Corresponding author, Email: S.gohari@basu.ac.ir 